Elsevier required licence: (C) <2017>. This manuscript version is made available under the CC-BY-NC-ND 4.0 license http://creativecommons.org/licenses/bync-nd/4.0/ 


\title{
Making the next move: When does the newness of experience matter in overseas sequential entries of multinational companies?
}

\begin{abstract}
Traditional internationalization models suggest multinational companies (MNCs) can exploit their accumulative experience to facilitate their sequential entries. However, experience may depreciate over time. Thus, obtaining benefits from prior experience for MNCs is based on two critical premises, i.e., interpreting and applying experience correctly. We argue that there is a need to study the newness dimension of experiential learning. In doing so, we aim to explore to what extent the newness of experience matters in overseas sequential entries for MNCs. Moreover, we expect that the benefits from recent experience in guiding sequential entries are contingent on the extent of context similarity between the most recent entry location and sequential entry location and the outcome expectancy of focal entry. With a sample of 112 Chinese listed firms and 410 observations during the period of 2000-2012, we find that else being equal, the newness of experience of MNCs is positively associated with sequential entry and such a relationship is positively moderated both by context similarity in institutional environment and the outcome expectancy of the focal entry. We also compare the effects of the newness of different types of experience and find that the newness of the most recent experience has a larger influence on sequential entry than location-specific experience and general experience.
\end{abstract}

Key words: newness of experience, context similarity, outcome expectancy, sequential location choice 


\section{Making the next move: When does the newness of experience matter in overseas sequential entries of multinational companies?}

\section{Introduction}

Building a strong network of foreign operations around the world is an important aspect of global strategy for multinational companies (MNCs) (Chang, 1995). In order to get effective operations around the world, one major consideration is strategically arranging the layout of every discrete location choice for overseas subsidiaries (Kim \& Hwang, 1992). However, it is worth noting that a large body of prior literature often implicitly treats location decisions as dependent and discrete (Baum, Li, \& Usher, 2000; Belderbos, Olffen, \& Zou, 2011; Hernández \& Nieto, 2015; Huett, Baum, Schwens \& Kabst, 2014; Ramasamy, Yeung, \& Laforet, 2012; Wang, Hong, Kafouros, \& Wright, 2012). Considering the dynamic process of MNCs' internationalization and the potential path-dependent nature in overseas investment decisions, MNCs' prior entry location choices may have an important influence on following entry choices (Chang \& Rosenzweig, 2001b; Kogut, 1983; Nachum \& Song, 2011).

Actually, the idea that MNCs are making sequential investment has been already noted in early international business literatures. A dominant perspective is the traditional internationalization process model proposed by Johanson and Vahlne (1977) who suggested that a firm starts from exports to a country, or starts in countries that were close to home country in terms of psychic distance. After gaining certain experience abroad, MNCs then gradually establish local production subsidiaries or enter other countries that were further away in psychic distance terms (Johanson \& Vahlne, 2009). Following the traditional internationalization model, an increasing number of research focuses on the cumulative dimension of experiential learning (in terms of the frequency or the duration of overseas investment) on sequential entry strategies (Baum, et al., 2000; Chang, 1995; Chang \& 
Rosenzweig, 2001; Davidson, 1980; Delios \& Henisz, 2003; Gao \& Pan, 2010; Kogut \& Chang, 1996; Xia, Boal, \& Delios, 2009). These studies have reached a broad consensus that MNCs can make follow-up sequential choices through prior experience in a particular country which allows them to gain knowledge about the host country and build local networks to overcome liability of foreignness (Anand \& Delios, 1997; Lu, Liu, Wright, \& Filatotchev, 2014; Sethi \& Guisinger, 2002). The basic assumption of this is that the knowledge drawn from prior experience is constant and remains useful over time. As such, an important dimension of experience, i.e., the newness of experience which is defined as to what extent international knowledge is drawn from recent experience rather than from experience longer ago, is largely neglected in prior studies. In fact, organizational knowledge is not static; instead, it is created, refined, altered, and discarded as organization members' experience develop and update old knowledge into new look to reflect their lessons they draw from recent experience over time (Argote, Beckman \& Epple, 1990; Heeley \& Jacobson, 2008; Huber, 1991; Levitt \& March, 1988). One exception in the prior studies is Nachum and Song (2011)'s study which empirically examines the impact of the age of prior experience and finds that the influence of the age of experience is limited in law service industry. But such a finding in a specific industry for which experience may remain useful for many years, might be less generalizable to other industries in which technological and market uncertainties are often quite high. In this paper, we purposively attempt to fill in this gap by answering following questions in a broader set of industries: 1) Will the effect of experience decay in determining MNCs' sequential entries? 2) Will the effects of different types of experience decay in a different way? and 3) In what conditions, the decay of experience will change?

In this article, we build upon the prior research on sequential investment and extend the traditional internationalization process model by applying organizational learning theory to examine the effect of the newness of experience in sequential entries. Especially, we focus on 
the sequence of location choices for which MNCs need to decide which country to locate first, and which is the next, as well as the number of OFDI incidents in focal country. For example, a given firm A invested in America in 2000, Canada in 2005 and Africa in 2010. Then, is it higher possibility for firm A to make the next new subsidiary in Africa rather than in America or Canada and is it also higher likelihood that firms will make more investments in Africa when the entry event in Africa is the most recent experience?

Following organizational learning perspective, efficient learning from prior experience is based on two critical premises (Levinthal \& March, 1993; Zeng, Shenkar, Lee, \& Song, 2013). On the one hand, prior activities should be correctly interpreted so that causalities can be effectively untangled. On the other hand, prior valuable knowledge will be applied appropriately to subsequent entries even context changes (Levinthal \& March, 1993; Levitt \& March, 1988; Zeng, et al., 2013). Based on this logic, we firstly argue that new experience may be more beneficial than distant experience in terms of correct interpretation and appropriate application.

However, the influence of the newness of experience on sequential entry varies with different types of experience. In order to address this issue, we decompose internationalization experience into three categories, namely the most recent experience, location-specific experience and general experience. As shown in Figure 1, the newness of the most recent experience is defined as the time difference between the focal entry and the most recent one. The newness of location-specific experience is described as the experience drawn from those prior entries except for the most recent entry within the same location as the focal entry (i.e., entry 1 and entry 3), while the newness of general experience reflects the experience drawn from prior entry portfolio (i.e. entry 1,2,3,4, and 5). In doing so, we argue that the newness of the most recent experience is most influential in determining the sequential entries than the other two. 


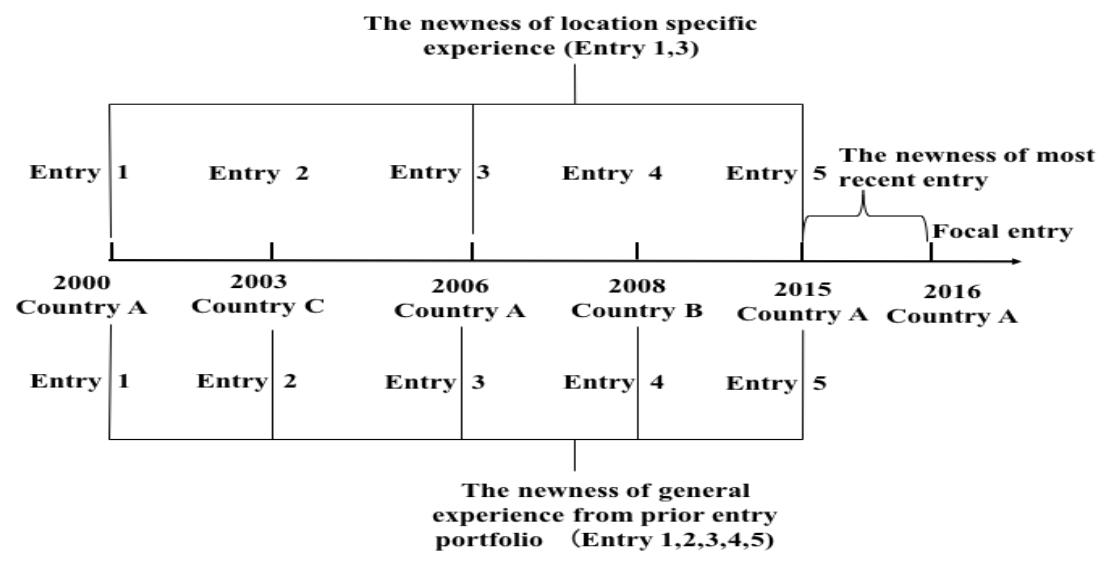

Figure 1 The newness of the three types of experience

Further, the role played by the newness of experience in sequential entries may be contingent. According to organizational learning theory, the impact of new experience on sequential entries probably depends on the extent to which the new experience is reutilized (Levinthal \& March, 1993). Specifically, the boundaries of exploiting new experience often arise from two types of contingent factors: context similarity in terms of institutional environment similarity between the most recent entry location and sequential entry location and MNCs' outcome expectancy of the focal entry, which are closely associated with the correct interpretation and appropriate application of internationalization experience. We expect that if the institutional context for transferring new experience is extremely different from sequential entry, it will lead to biases of experience application and thereby setting obstacles to gaining benefits from new entry (Ho \& Wang, 2015; Petersen, Pedersen, \& Lyles, 2008; Zeng, et al., 2013). We also expect that if MNCs have a positive outcome expectancy of focal entry, they are more inclined to repeat recent entry decision because managers' positive judgment of recent entry make them more confident to invest corresponding resources for interpretation and application of prior experience.

With a sample of 112 Chinese listed multinational firms and 410 observations during the period of 2000-2012, we attempt to make three contributions to the existing studies. First, we extend the traditional internationalization theory which often view learning as a statically 
cumulative nature (Hotho, Lyles, \& Easterby-Smith, 2015). Actually, there are two dimensions for depicting experiential learning, i.e. accumulative nature of experience and the newness of experience, for which the former has been widely investigated in sequential entry studies while the latter has been largely overlooked in the research field of international business. By investigating the effect of the newness of experience on sequential entries, we can provide theoretical explanations for how the time issue of experience benefits sequential entries in terms of the mechanisms of experience interpretation and application. Second, we go further in exploring variances of decay from different types of experience. These in-depth comparisons offer a better understanding of experience decay and add to our limited knowledge about the effect of the newness of experience. Finally, we empirically investigate the boundaries of repeating past experience and answer why there are heterogeneous behaviors among MNCs in exploiting their new experience. Specifically, we argue that the relationship between the newness of experience and sequential entry is contingent on context similarity and outcome expectancy of MNCs. This complements existing studies in identifying the conditions for the decay of experience.

\section{Theoretical background}

\subsection{Location choices in foreign investment}

Before making decisions on how to perform activities in foreign markets, MNCs need to choose which foreign markets to enter. There are three lines of research making explanations for location choices of foreign entries, in particular based on geographic economics, institutional theory and organizational learning perspectives (Alcácer \& Chung, 2007; Belderbos, et al., 2011; Chang \& Park, 2005; Chang \& Rosenzweig, 2001; Guillén, 2002; Li, Yang, \& Yue, 2007). The dominant logic of geographic economics is that firms locating in the vicinity of other economic activities can obtain positive spillovers from these agglomerated 
firms and reduce uncertainty (Alcácer, 2006; Delios \& Henisz, 2000). Meanwhile, institutional theory suggests that firms mimic the behavior of prior entry of other firms in order to gain legitimacy under uncertain situation (Chan, Makino, \& Isobe, 2006; Witold J. Henisz \& Delios, 2001). However, most often, prior studies following these two research streams treat foreign entries as discrete and independent rather than as a sequence. As stated by Kogut (1983), foreign investment is a sequential process and without regarding to this sequential ordering will lead to underestimate the possible effects of prior entry on subsequent new entry. Depart from the prior two perspectives, the third line of research taking organizational learning perspective treats location choices in a dynamic way. As summarized in Table 1, three dimensions of experience are relevant to sequential entry research, i.e., experience depth, experience diversity and the age of experience. It should be noted that most of the literature focus on the influence of experience depth on sequential entry. For example, Johanson and Vahlne (1977) examine the internationalization sequence of Swedish multinationals and describe internationalization process model as follows: a firm starts by exporting to a country; then establish a selling subsidiary; finally, it builds a manufacturing entity. Regarding the location pattern, Johanson and Vahlne (1977) also conclude that internationalization starts in less psychic distance and then sequentially enters into psychically distant countries. Davidson (1980) shows that the prior presence of a firm in a country increases the probability of a new investment there rather than in other countries. In addition, Chang and Rosenzweig (2001b) and Zhang, Zhang, and Liu (2007) find an increasing commitment on sequential entry by the accumulation of knowledge about the host country. It is worth noting that the path-dependency of foreign entries and the effect of the age of experience have not been explicitly investigated in these prior studies. Nachum and Song (2011), as one of the few exceptions, examine the moderating effects of experience diversity and age of prior entry portfolio on subsequent moves with a sample from legal service 
industry. Their empirical results suggest slow depreciation of knowledge in legal services firms. However, in other industries, it is possible that the depreciation of knowledge is faster than in legal service industry as the latter industry is based on the application of laws that changes slowly (Boone, Ganeshan, \& Hicks, 2008). Indeed, some researchers claim that knowledge depreciation varies widely across different industrial settings (Benkard, 1999; Epple, Argote, \& Devadas, 1991).

\section{Insert Table 1 about here}

\subsection{Experience and sequential entry choices}

According to organizational learning theory, experience refers to an organization's historical memory of routines that create learning economies when retrieved and replicated (Cyert \& March, 1963; Levitt \& March, 1988; Nelson \& Winter, 2009). In the international business context, many studies have examined that prior experience play an important role in shaping foreign outward investments (Caves \& Mehra, 1986; Lu, et al., 2014; Slangen \& Hennart, 2008; Vermeulen \& Barkema, 2002). Through incremental internationalization process, MNCs tap into local knowledge and networks of host country to buffer the adverse effects of liability of foreignness (Johanson \& Vahlne, 1977). Thus, it is expected that MNC's prior experience will have beneficial effect on the follow-up new investment.

However, few studies have noticed the detrimental effect of experience (Barkema, Bell, \& Pennings, 1996; Gaur \& Lu, 2007; Zeng, et al., 2013). For instance, Hayward (2002) finds that the skillful acquirers in big companies like Cisco Systems or General Electric have great potential to learn from their acquisition experience, but generally fail to realize that potential. One explanation of Hayward (2002) is that inferences from experience are particularly valuable in a timely fashion. Why do some firms exploiting experience from 
long ago and failed? Following this, it is imperative to question the quality of experiential learning, especially the time issue of experience, rather than quantity of experience.

Based on organizational learning theory, the notion that prior experience may benefit subsequent activities should be based on two premises. On the one hand, prior activities should be correctively interpreted (Levinthal \& March, 1993; Levitt \& March, 1988). It means that organization needs to draw correct interferences from past experience to untangle the exact causalities of actions and outcomes. However, when time elapses, the value of existing knowledge may be reduced (Nachum \& Song, 2011). The casual relationship of prior events can be ambiguous and doubtful. Additionally, certain properties of experience interpretation are largely contingent on characteristics of individual inference and judgment (Levitt \& March, 1988). For example, managers with overconfidence often attribute poor performance to poor execution or external factors rather than conclude that experience itself is fundamentally flawed (Haleblian, Kim, \& Rajagopalan, 2006). Thus, if we draw erroneous inferences from prior experience, the opposite will hold true, with experience misguiding firms in sequential activities (Huber, 1991; Zeng, et al., 2013).

Experience will matter in the sequential activities only if firms choose to apply it after interpretation of the experience. So on the other hand, prior valuable knowledge should be applied appropriately to subsequent entries even context changes (Levitt \& March, 1988; Zeng, et al., 2013). As Lubatkin, Calori, Very, and Veiga (1998) noted that British companies suffered decreased performance because of exploiting their domestic control structures in French acquisitions. Haleblian and Finkelstein (1999) also found that inappropriately applied experience into dissimilar situation will cause poor performance. Hence, the inappropriate applications to new situations are eroding for multinational companies. 
Based on this logic, we disaggregate experience into distant experience and new experience and attempt to explicate how the newness of experience influences the sequential entry for MNCs through mechanisms of interpretation and application of experience. Our basic argument is that the newness of experience has a positive influence on sequential entry. In order to systematically test the depreciation of experience, we decompose experience into three types, such as the most recent experience, location-specific experience and general experience.

Toward a dynamic perspective to explain MNCs' internationalization strategy, in this paper, we explore the influence the newness of experience on sequential entries in two ways. Firstly, we study how the newness of experience affects subsequent location choices. In doing so, we test the impact of the newness of the most recent experience and compare the relative effect between the newness of the most recent entry and the newness of location-specific experience on subsequent location choice. Second, we also test how the newness of experience influence a time-varying variable, namely the number of outward foreign direct investment (OFDI) incidents. These will be explained further in next section. Figure 2 is the research model for this paper.

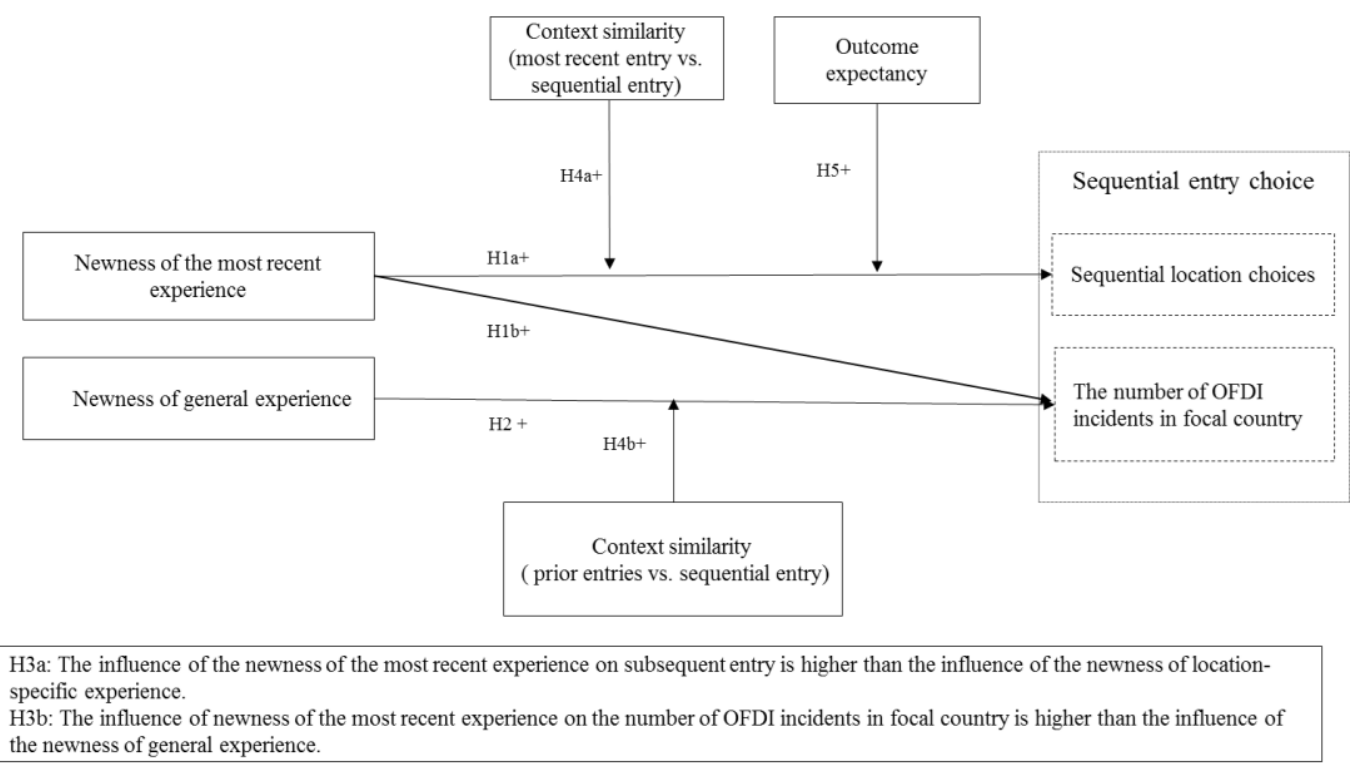


Figure 2 Research model

\section{Hypotheses development}

\subsection{Newness of experience and sequential entries}

As suggested by organizational learning theory, experience allows firms to get more benefits in overcoming liability of foreignness in sequential entries (Levinthal \& March, 1993; Levitt \& March, 1988). By subsequently setting new subsidiaries in the same country, MNCs not only can effectively exploit prior experience to achieve scale economies in production and marketing, but also enable them to deepen their understanding of a business context and improve capabilities to adapt to local conditions (Audia, Locke, \& Smith, 2000; Davidson, 1980; Lu, et al., 2014). Hence, experience with a host country encourages firms to select the country for further new investment instead of entering into a new country. Even exploiting prior experience in guiding sequential entry strategy, experience accumulated from the most recent or distant activities may have heterogeneous impact on sequential location choices. We expect that the most recent experience is more useful than distant experience both in sequential location choices and in bringing about more OFDI incidents in focal country.

Firstly, the most recent experience will reduce the biases in interpretation of experience. From a point of view of organizational memory, new experience means organizations remember the holistic details of the last entry without the changes of organizations structure or staff loss. Therefore, organizations can search the cause and effect of the total process more efficiently and accurately (Argote, et al., 1990; Madsen \& Desai, 2010). In contrast, the value of distant experience depreciates over time because "forgetting" may occur in organizations (Baloff, 1967; Benkard, 1999). For example, organizational members who have been through the total process of internationalization may exit taking a piece of 
organization knowledge with them, or some big transformations of organizational structures and processes may disrupt the existing organizational memory, or some unintended, random and small changes to tacit routines over time also make gradual erosion of knowledge stores (Darr, et al., 1995; Holan \& Phillips, 2004; Madsen \& Desai, 2010). As a result, the ambiguities of causalities will increase. Besides, distant experience is more likely to be routinized and repeated frequently than new experience. Ample evidence suggests that more experienced organizations are more likely to repeat the same strategic action garnered from prior experience because it can supplement or even substitute for fussy calculative and formal decision-making rules (Haleblian, et al., 2006). In this case, the choices made by managers are faster and overconfident without extra hesitations even it may draw incorrect inferences (Chen, Crossland, \& Luo, 2014; Kim, Kim, \& Miner, 2009). In contrast, the knowledge of causality from the most recent experience is less likely to nurture such overconfidence because of the lower probability of the formation of organizational inertia, the less likelihood of being misspecified and misinterpreted (Heimeriks, 2010; Zeng, et al., 2013). Hence, when making interpretation of experience for sequential entries, the most recent experience are more likely to untangle the ambiguities of complicated outward investment process and draw accurate conclusions than distant experience.

Secondly, the most recent experience is more likely to increase the applicability of experience. New experience is obtained in a timely fashion. Rather than exploiting distant experience that may be out of legitimate demand of environment requirement, recent one is more legitimate for MNCs amongst different stakeholders in changing environment (Baum, et al., 2000). Just as noted by Cyert and March (1963), the effective solutions begin with the most recently used ones. Further, exploiting recent experience is advantageous for firms to adjust their strategy flexibly before new experience is stored in organizational memory. In this way, MNCs can efficiently respond to the changing demand of host countries such as 
technological breakthroughs, regulatory transformations or alterations in trade barriers (Haveman, 1992). Thus, firms applying new experience are more likely to both get legitimacy from stakeholders and cope with fast-changing environment while distant experience cannot hold them simultaneously.

Taken together, the benefits of referring recent experience instead of refereeing distant one increase and the risk of investing the same host country also decrease in this case. It is superior for MNCs to follow the most recent entry in making sequential entry decisions.

Hypothesis 1a: Else being equal, the newness of the most recent experience is positively associated with the likelihood of choosing the same location as the most recent one.

Hypothesis 1b: Else being equal, the newness of the most recent experience is positively associated with the number of OFDI incidents in focal country.

By definition, general experience is transferrable across different countries for MNCs in international entries. Such general experience will enhance a firm's capability of managing international operations, which may be about how to respond to overseas uncertainties from large institutional and cultural difference and how to establish routines to organize and coordinate employees within organizations (Li \& Meyer, 2009). However, the value of general experience may deteriorates over time (Henderson \& Cool, 2003). For instance, managers who are responsible for outward decision may have left the office or moved to another department, taking their personal knowledge away with them (Holan \& Phillips, 2004). Thus MNCs would miss some part of important knowledge and encounter interpretation bias problem. In such circumstances, MNCs would take incorrect actions when facing unfamiliar and uncertain environment. Also, those overseas operating routines which need the attention and involvements of experienced managers in careful execution are more likely to lead to failure. In addition, especially in constantly changing environment, 
knowledge deterioration often renders prior knowledge obsolete (Baum, et al., 2000). As a result, general experience may not be correctly applied as expected (Henderson \& Cool, 2003; Nachum \& Song, 2011).

In contrast, more recent knowledge is better because firms can easily recall what happened in last foreign entry and then efficiently analyses its causal relationships (Henderson \& Cool, 2003). In doing so, MNCs with up-to-date knowledge are capable of responding to the changing environment flexibly. Therefore, we expect that more recent general knowledge will positively influence the number of investments in sequential entry country.

Hypothesis 2: Else being equal, the newness of general experience from prior entry portfolio is positively associated with the number of OFDI incidents in focal country.

For different types of experience, the influences of experience newness on sequential entry differ by their ease of causality interpretation and their ease of adapting to changing environment. We argue that the most recent experience, compared with location-specific experience and general experience, is more sensitive to experience newness.

Although both general experience and the most recent experience may decay over time, general knowledge would not be influenced by such a decaying effect as significant as the most recent experience. This is because general knowledge is generally universal across different contexts, and such routinized and transferrable guidelines are often not easily modified over time (Crossan, Lane, \& White, 1999). For example, firms can develop a generic M\&A management process for international acquisitions including the procedure to screen, select and source outside resources (Nadolska \& Barkema, 2007). Once such generic procedure is set up, it cannot be easily broken unless radical changes happen in external environment. Similarly, location-specific experience offers rich information about 
the specific political and cultural environment in a certain country (Li \& Meyer, 2009). In a relatively short time period, the specific knowledge in a given country does not change as quickly as the most recent experience do. Culture, for example, is embedded deeply into local society and thereby is not so easily eroded by time (Hofstede, 1980). That is why in prior studies related to national culture (e.g., Beugelsdijk, Maseland \& Hoorn, 2015), culture data in Hofstede's scores is as relevant now as it was many years ago. Therefore, compared with the most recent experience, general experience and location-specific experience are less sensitive to the decaying effect over time.

Furthermore, in the whole sequence of international entry decisions a firm has made, the most recent experience is the closest one to focal entry decision. Managers with a clearer memory of the most recent knowledge can enjoy the legitimacy and confidence when interpret and apply such relevant and up-to-date knowledge for guiding sequential entry (Nachum \& Song, 2011). As a result, firms are apt to weigh the most recent events more heavily than events that are general or location-specific. Hence, the most recent experience depend much on the newness nature of experience.

Hypothesis 3a: Else being equal, the influence of the newness of the most recent experience on subsequent entry is higher than the influence of the newness of location-specific experience.

Hypothesis 3b: Else being equal, the influence of newness of the most recent experience on the number of OFDI incidents in focal country is higher than the influence of the newness of general experience.

\subsection{Newness of experience, context similarity and sequential entry}

Although the newness of experience has a positive effect on sequential location choices, the question to what extent that recent experience can be efficiently repeated in a 
new context is still left to be answered. There are some boundary conditions needs to be considered. The value of prior experience in foreign entries highly depends on the degree to which the application context of experience is institutionally similar to a future event. Generally, MNCs have to interact with their external institutions and get local acceptance so as to overcome liability of foreignness. However, different host countries have different institutions that do not allow the simple transfer of business practices across borders (Dikova, Sahib, \& van Witteloostuijn, 2010; Salomon \& Wu, 2012; Xu \& Shenkar, 2002). For instance, formal regulations and rules of intellectual property rights are more exhaustive, clearly laid out and better enforced in US than other emerging countries like India or Africa. MNCs may have higher knowledge gaps between knowledge possessed and the knowledge needed for efficient operations in sequential entry contexts (Eden \& Miller, 2004; Kostova, 1999; Petersen, et al., 2008). Thus, although the newness of the most recent experience positively associates with the likelihood of choosing the same location as the most recent one, the extent to which a firm applies the most recent experience in guiding sequential entry depends on the context similarity between the most recent entry location and sequential entry location country and the most recent-entry country. When the institutional context between the most recent entry country and the sequential entry country is different, it will impede MNCs' understanding of local rules and culture, local market and related stakeholders in sequential entries (Gooris \& Peeters, 2014). Hence, although the most recent experience is not likely to be quickly forgotten by firms, the large institutional difference still increases the possibility of interpretation bias for the most recent knowledge. The increasing context dissimilarity between two different countries also make recent experience out of date and thus not fit with sequential country's legitimate demand (Perkins, 2014). Further, due to the changing demand of different host countries, MNCs are less likely to be able to assess the expectations of dissimilar institutions and may feel reluctant 
to flexibly sense and apply the most recent knowledge to sequential entry (Gaur \& Lu, 2007). On the contrary, experience gained from institutionally similar deals is more beneficial to sequential entry (Hernández \& Nieto, 2015; Muehlfeld, Rao Sahib, \& Van Witteloostuijn, 2012). In a similar context, MNCs will have the advantage in understanding the context of business codes, regulatory rules, norms and practices (Barkema, et al., 1996). These institutionally related experiences provide MNCs with a more precise ability to interpret, predict and mitigate obstacles coming from new institutional environments (Slangen \& Hennart, 2008). In addition, the similar context also enables MNCs to enjoy the increasing external legitimacy by local stakeholders and thereby increasing the adaptation efficiency when applying the most recent experience (Perkins, 2014). As a whole, context similarity between sequential entry and the most recent entry increase a firm's ability to make correct interpretation and application of the most recent experience, thereby strengthening the positive relationship between the newness of the most recent entry and sequential location choice.

Based on the same logic, this is also the case for context similarity to moderate the relationship between the newness of general experience and the number of OFDI incidents in focal country. When treating the prior entries as a portfolio, context similarity is not solely the institutional difference between home country and host country or between focal entry and last entry. As noted by Zhou, and Guillén (2015), they propose a concept of "home base" to denote the combination of countries in which the firm has accumulated through prior operations until a given point in time including home country. It is assumed that MNCs can learn from various host countries over time by prior entries and institutional uncertainty they face changes with their international expansion. In this condition, the real problem MNCs encounter is the institutional distance between home base (a set of countries in prior entries) and the host country. When context similarity between prior entries and 
sequential entry is high, MNCs can be more efficient to interpret and apply general experience to sequential OFDI activity, thus increasing the possibilities for making more OFDI incidents in focal country. Hence, we posit the following:

Hypothesis 4a: Else being equal, the positive relationship between the newness of the most recent experience and the likelihood of choosing the same location choice as the most recent one will be stronger when institutional context between the most recent entry location and sequential entry location is similar.

Hypothesis 4b: Else being equal, the positive relationship between the newness of general experience and the number of OFDI incidents in focal country will be stronger when institutional context between prior entry locations and sequential entry location is similar.

\subsection{Newness of recent experience, outcome expectancy and sequential entries}

Not only context similarity could be a contingent factor influencing the reutilization of recent experience, but also MNCs' outcome expectancy of focal entry will affect the relationship between the newness of the most recent experience and sequential location choices. MNCs' managers will have judgments about future actions for cross-borders and modify their behavior based on the performance of current activities (Kim, et al., 2009). The condition of current activities will have great influence on MNC's willingness to whether exploit knowledge gained from recent experience or not (Bunderson \& Sutcliffe, 2002; Wowak \& Hambrick, 2010). Given a positive signal of recent activity, it proves an effective and successful execution of the most recent action in current environment. This will lead positive outcome expectancy of MNCs which the perceived likelihood of success for next move is higher (Greve, 2003; Levinthal \& March, 1993). As a result, stakeholders within organizations not only will give endorsement of the appropriateness of such strategic choice, 
but also will increase the confidence for further investment; moreover, they will prefer to follow this efficient practice instead of trying a new one (Audia, et al., 2000; Haleblian, et al., 2006; Xia, et al., 2009). In this case, we argue that MNCs' outcome expectancy will enhance their capabilities of experience interpretation and application and strengthen the positive relationship between newness of the most recent experience and sequential location choices.

The fundamental reason for this argument is that experience needs rich commitments for interpretation, and organizations will allocate more resources in searching the casual relationships between the actions and outcomes of the most recent experience when they have positive outcome expectancies (Schwab \& Miner, 2008). Through repeated analysis of recent activity, it deepens the MNC's memory of the whole investment process and makes the most recent experience more codified, accurate and salient to them. Simultaneously, such positive outcome signal directs MNCs to concentrate their resources to explore the exact causalities so as to reduce misattributions and interpretation biases (Grinblatt \& Keloharju, 2009; Xia, et al., 2009). In contrast, if the most recent experience has negative feedback, organizational stakeholders with negative outcome expectancy become averse to make further commitment and push MNCs to abandon to make further efforts in new experience (Hayward, 2002). In other words, they are more likely to make strategic change and engage in "problem search" to figure out the alternative strategies (Miller \& Chen, 1994). At the same time, managers will be more inclined to attribute the failure to unforeseeable factors and ignore the corrective feedback, so that they are less willing to examine the real sources of errors (Gosling, Denizeau, \& Oberlé, 2006). All these will increase the likelihood of misinterpretation.

Besides, positive outcome expectancy will also strengthen the experience application capability of MNCs. Due to resource scarcity, parent firms have to make strategic priority 
considerations ( $\mathrm{Lu} \& \mathrm{Xu}, 2006)$. When they have positive expectancy of focal entry, organizations will be more supportive by providing sufficient resources in applying the most recent experience, such as allocating more employees for backup, searching more local information needed and being more engaged in building local networks (Anand \& Delios, 1997; Lu, et al., 2014). Simultaneously, it stimulates slack search which not only can help firms incrementally improve existing routines, but also can generate innovative knowledge that enhance adaptive capabilities even when environment changes (Baum, Rowley, Shipilov, \& Chuang, 2005; Greve, 2003). Consequently, by flexibly responding to changing environment, it improves MNC's ability to apply the most recent experience for sequential investment. Thus, we posit that,

Hypothesis 5: Else being equal, the positive relationship between the newness of the most recent experience and the likelihood of choosing the same location choice as the recent one will be stronger when MNCs have positive outcome expectancy of focal entry.

\section{Methodology}

\subsection{Research setting and sample}

After the policy of "Go global" since early 2000s (Buckley, et al., 2007; Luo, Xue, \& Han, 2010), Chinese non-financial outward direct investment reached \$878 billion in 2012 and remains the third-largest outbound investor in the world (Chinese OFDI report in 2012 from Ministry of Commerce of the People's Republic of China ) ${ }^{1}$. During more than a decade OFDI so far, Chinese outward investments have covered over 179 countries, accounting for $76.8 \%$ of total countries. Thus, Chinese overseas investment incidents provide an appropriate empirical context to test our hypotheses. We constructed a data set by matching two secondary sources about Chinese OFDI firms. Firstly, we used OFDI events list from the 
Ministry of Commerce of China (MOC). MOC is a major ministry at the central government level promoting and managing Chinese OFDI (Luo, et al., 2010). Every new OFDI project conducted by MNCs must be released by MOC. This data source provides a brief introduction of each OFDI project (e.g. investment location, industry, date of approval, line of business etc.). Secondly, we cross-checked the OFDI projects with the annual reports of Chinese firms listed in Shanghai and Shenzhen Stock Exchange of China and got subsidiary-level data (Lu, et al., 2014; Xia, Ma, Lu, \& Yiu, 2014). After merging these two data sources, we got an original dataset including 1,050 observations of OFDI made by Chinese listed firms during the period of 1992-2012.

We selected our research samples based on the following procedure. Firstly, we excluded the following entry incidents from our dataset: (1) foreign entry events in terms of offices and representative institutions in host country, because such entries need very little commitment, and (2) investments projects in Hong Kong, Macau and any other tax heavens because OFDI to these destinations are driven by tax considerations (Hampton \& Christensen, 2002; Lu, et al., 2014). Then, we deleted missing samples that have not released the exact date of conducting OFDI project concerning our major measurement of the newness of experience. We also deleted the samples that did not have sequential entries because there were no sequential location choices for them. The raw data for institutional distance measurement is obtained from the World Bank's Governance Indicators (WGIs) which have been widely used on the impact of institutions on firms' internationalization decisions (e.g. Ang, Benischke, \& Doh, 2014; Cantwell, Dunning, \& Lundan, 2010; Siegel \& Larson, 2009). Thus, we restrict our sample to the 1997-2012 periods because the World Governance Indices (WGIs) are available from 1996 to 2012. In the end, our final sample consists of 112 firms leading to 410 observations during the period of 2000 to 2012. Concerning the potential sample-selection biases in our analyses, we conduct the T-test between our samples and original data, the result 
for investment amount, sales income, the number of employees, and total assets of firms showed no significant sample-selection bias. Thus, sample-selection bias is not the major problem and our sample has a good representation for the study. In running regression analyses, we lagged all independent variable by one year to avoid possible endogeneity problems.

\subsection{Measures}

\subsubsection{Dependent variable}

We have two dependent variables in our study. One is Sequential entry dummy, which equals 1 if a sample firm has conducted a new entry in a given host country which is the same location as the most recent entry in a given year and 0 otherwise. The other one is the count of OFDI incidents (i.e. foreign subsidiaries established by a Chinese firm) until the given year in a given country. For example, firm A has conducted three investments, i.e., one in America in 2000 and two in India in 2005 and 2010 respectively. If firm A make new entry into India in focal year, we will code sequential entry dummy as 1 and 0 otherwise. Meanwhile, we code the number of OFDI incidents in focal country as 2 because there are two investments in India until the focal year.

\subsubsection{Independent variable and moderating variables}

4.2.2.1. Newness of experience. In our dataset, the date of declaration for OFDI project marks the beginning of the project. We follow Hayward (2002) to operationalize Newness of experience. With regards to the newness of the most recent experience, we firstly measure time difference as the number of days between the focal entry and the most recent entry. Then, to facilitate the interpretation, we reverse this measure by using the following formulations and measure the newness of the most recent experience, in which Time Difference maximize is the maximum value of Time difference in our sample (e.g. 3257): 
Newness_the most recent $=\operatorname{Ln}\left(1 /\right.$ Time difference $\left.{ }_{i t}\right)+\operatorname{Ln}($ Time difference maximize $)$

In doing so, the higher value indicates a higher impact from the most recent experience. Based on our definition, we measure Newness of location-specific experience by summing up the time difference between each location-specific entry and the focal entry and then reverse it by using the above formulation. Similarly, this method is also applied to the measurement of Newness of general experience.

4.2.2.2 Outcome expectancy. According to our logic, MNCs will have positive outcome expectancy if the performance of recent activity is confirmed to be optimistic. Due to data availability, it is difficult to measure the performance of every outward foreign investment directly. We then use financial performance of publicly listed companies (e.g. Tobin's Q) as a proxy to measure the performance of outward foreign investment project. Tobin's $Q$ is a widely used proxy for performance and it not only reflects the evaluation by the market of all of the information available to investors in stock market but also reflects investors' evaluations of the prospects of company (Feldman \& Montgomery, 2015; Miller, Xu, \& Mehrotra, 2015). As such, it is a better measurement for listed MNCs for the performance than other profit-based indexes because they are more easily to be manipulated by firms (Shleifer \& Vishny, 1997; Villalonga \& Amit, 2006). On the other hand, Tobin's Q implicitly uses the correct risk-adjusted discount rate, imputes equilibrium returns, and minimizes the distortion from tax laws and accounting conventions (Wernerfelt \& Montgomery, 1988). In the research field of performance feedback, performance feedback is often measured as the difference between a firm's performance and its historical aspiration (Gentry \& Shen, 2013; Lyer \& Miller, 2008). Thus, we follow this measurement and then construct a dichotomous variable, which equals 1 (e.g. positive outcome expectancy) if the Tobin's $Q$ at time $t$ is higher than Tobin's $\mathrm{Q}$ at time t-1 and 0 (negative outcome expectancy) otherwise. There are two reasons for choosing one-year window. Firstly, the evaluation of prior action is a complicated 
task because different strategic activities always have mixed signals to managers. According to behavior researchers who suggested that decision makers rely heavily on the most recent information to reduce their cognitive complexities and simplify their evaluation processing (Hogarth \& Einhorn, 1992), the action occurred during a year will have great influence on outcome expectancy. Second, as the average value of time difference between two outward investments is nearly one year in our sample (e.g. 379), one-year lag is appropriate for testing the performance of recent activity. In addition, the value of Tobin's Q has been adjusted by subtracting the average performance of the industry because different industries have large difference in performance (Audia, et al., 2000). We obtain this data of Tobin's Q from China Stock Market \& Accounting Research Database (CSMAR) database which is a well-known database for financial information of Chinese listed companies (Kato \& Long, 2006).

4.2.2.3 Context similarity. Many literatures argue that institutions of different host countries are important factor to determine the transferability of knowledge (Xu \& Shenkar, 2002). Thus, the extent to which institutional environment between the most recent entry country and sequential-entry country is similar is a proxy for context similarity in our study. In order to test this contingent effect, we measure context similarity based on WGIs established by the World Bank (Kaufmann, Kraay, \& Mastruzzi, 2005). The WGIs have been used in a wide range of studies of the impact of institutional environment on firms' internationalization decisions (e.g. Ang, et al., 2014; Cantwell, et al., 2010; Siegel \& Larson, 2009). It has six dimensions including voice and accountability, political instability and violence, government effectiveness, regulatory quality, rule of law, and control of corruption. Overall, they address various aspects of institutions such as political, civil and human rights, market restrictions, predictability of legal decisions, and law in action and corruption (Kaufmann, et al., 2005). The database ranges from 1996 to 2012 covering 209 countries and territories, and the scores range from -2.5 to 2.5 (the higher the score, the better the institutional environment is). We 
take the average value of the above-mentioned six dimensions to measure institutional distance because six dimensions are highly related and principal component analysis results show that above $85 \%$ is explained by one factor. Then, we measure context difference as the absolute difference of WGIs value between the most recent entry location and sequential entry location and reverse it using following formula.

Context similarity $=1-\frac{\text { Context difference }- \text { Context difference }}{\min }$

In doing so, the higher the value of context similarity means institutional difference between the most recent entry location and sequential-entry location is small.

As to measure the Context similarity between prior entry locations and sequential entry location for testing Hypothesis $3 \mathrm{~b}$, we follow the same method except for the measurement of context difference. We measure context difference between prior entry locations and sequential entry location followed the formulations below,

$$
\text { Context difference } \text { Prior entries vs.focal entry }=\left|\frac{\sum_{0}^{k} \mathrm{ID}_{i}}{k}-\right| \mathrm{ID}_{\text {focal }}||
$$

where $I D_{i}$ is the institutional distance between China and the focal country for the $i_{t h}$ investment and $\mathrm{k}$ is total number of investments prior to sequential investment. $I D_{\text {focal }}$ stands for the institutional distance value between China and sequential country. Hence, we calculate a difference between the former part and later part and take the absolute value. For example, if a firm invested in America in 2001 and England in 2002, and the sequential investment is in Thailand in 2003. Institutional scores for America, England, Thailand and China are 2, 2.5, 0.5 and 1 , respectively. Then, the context difference between prior entry locations and sequential entry location is $[(2-0.5)+(2.5-0.5)] / 2-(1-0.5)=1.25$. Then, we use the above formulation to reverse context difference into context similarity. 


\subsubsection{Control Variables}

This study also includes a set of control variables at the country, industry and firm levels. At the country level, as prior studies have confirmed that country distance between host country and home country have a profound influence on location choices (Berry, Guillén, \& Zhou, 2010; Blanc-Brude, Cookson, Piesse, \& Strange, 2014). Actually, there are various kinds of cross-national distance and prior studies have stressed that we should not only consider a single dimension of distance (Holburn \& Zelner, 2010). As there is no existing dataset perfectly covering all dimensions of distance, we include different distances from two sources. In doing so, we can also to some extent avoid common method bias with multiple data sources. Cultural distance, administrative distance, demographic distance, and geographic distance are obtained from database developed by Berry, Guillén, and Zhou (2010). Culture distance creates a knowledge gap that may prevent MNCs to fully decipher elements of existing knowledge (Zeng, et al., 2013). We control for cultural distance and measured it as the differences in power distance, uncertainty avoidance, individualism and masculinity. As Makino and Tsang (2011) and Lubatkin et al. (1998) argue that prior history between countries play an important role in reducing the foreign investment costs and uncertainty, we also control for administrative distance which is measured as differences in colonizer-colonized link, language, religion, and legal system. Demographic distance represents the differences in some demographic characteristics (Huynh, Mallik, \& Hettihewa, 2006). If there is a huge demographic difference between home country and host country, people's consumption habits are divergent and thus MNCs are reluctant to apply their prior knowledge in focal country. We measure Demographic distance as the differences in life expectancy, birth rate and populations. As geographically proximate countries have lower levels of economic and managerial costs in business operations across countries and thus will attract MNCs to enter into (Ojala, 2015), we also control for Geographic distance which is 
calculated as the distance between geographic centers of two countries. In addition, large institutional distance between home country and host country imply knowledge barriers for potential investors, deterring foreign market entry (Jiang, Holburn and Beamish, 2014). We control for the Institutional distance between home country and host country and measure it as the absolute value of difference between China and host country with the data from WGI dataset. It should be noted that institutional distance between China and host country is different from moderator variable (i.e., institutional distance between last entry and focal entry) although they are measured using a same dataset. Finally, we use the growth rate of GDP in host countries as a proxy to the Location importance of host country because country's market attractiveness has a great influence on location decision (Jiang, et al., 2014; Ramasamy et al., 2012). The data for GDP is obtained from a data source released by the International Monetary Fund.

Different industries may have different motives for going abroad (Quer, Claver \& Rienda, 2011). Thus at the industry level, we use a set of industry dummies coded as 1 if the subsidiary was in a given industry based on National Industry Classification Standard.

At the firm level, we control for firm size effects as previous studies argued that large firms are more advantageous to have available resources to overcome liability of foreignness (Chang \& Rosenzweig, 2001b). So the logarithm of the total assets of the firm at the time t-1 is measured as a proxy for Firm size. Apart from the time dimension of experience which is our present focus, the accumulative experience is also important for OFDI decision (Barkema \& Vermeulen, 1998). Prior studies have confirmed that both general experience and host-specific experience provide different information for decision-making ( $\mathrm{Li} \&$ Meyer, 2009). Thus we control for General experience, which is measured as total number count of investments conducted prior to the focal entry (e.g. Hayward, 2002). Host-specific experience is measured as the number count of investments conducted in a specific country prior to the 
focal entry (Xia, et al., 2009). Both of these two measures are based on counts while the newness of experience is based on time difference which is distinctive from the former two. Since a firm's international activities are interdependent and prior OFDI flow may influence the cash flow for the sequential entry, we also control for the OFDI flow as the amount of money MNCs have invested into the focal entry at time t-1 which is obtained in the firm's annual reports. In addition, previous studies found that State ownership provide firms with sufficient information which will mitigate their uncertainty to invest into new locations (Duanmu, 2012; Morck, Yeung, \& Zhao, 2008). We measure State ownership as the percentage of government ownership in MNCs (Delios, Wu, \& Zhou, 2006). Sample firms' ownership data were collected from CSMAR database which is widely used in previous studies (Kato \& Long, 2006). Further, Firm age is an indicator of organizational inertia as older firms generally are more bound by their history and have established routines for decision-making which may restrict firm's motivation to exploit recent experience (Xie, 2014). We measure it as firm's founding year subtracted by focal year (Xia, et al., 2014). Finally, we also include year dummies in our model to control for time effects.

\subsection{Method.}

As our first dependent variable, Sequential location choice, is dichotomous, a binary Probit regression model is appropriate for our analysis. The models were estimated with Stata 13.0. In addition, for our cross-sectional data, we follow Slangen and Hennart's (2008) methodology in accounting for cluster effects by using clustered standard errors (see Xu, Pan, \& Beamish, 2004 for further details) in our estimations.

Our second dependent variable, the count of OFDI incidents, suggest the need of using a count model, such as Poisson or negative binomial (NB) model. As the distribution of OFDI counts in our sample is over dispersed, NB model is more appropriate because Poisson model is fairly restrictive and require the mean and variance to be equal. In NB model, it generalizes 
the Poisson model and assumes the non-observable heterogeneity is distributed according to a Gamma function (Greene, 2003). We also use the Stata 13.0 to estimate NB model by the standard maximum likelihood method.

To test Hypotheses H3a, we need to compare the coefficient of the newness of the most recent experience and the newness of location-specific experience: $\beta_{\text {the most recent }}$ vs. $\beta_{\text {location-specific. We follow the method of Shi, Sun, Pinkham and Peng (2014). We first defined }}$

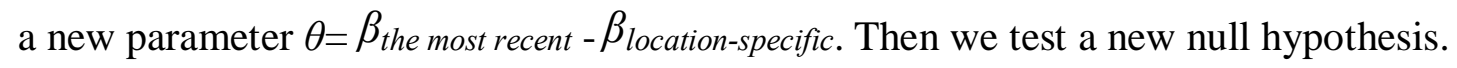

$\mathrm{H}_{o}: \theta=0$ vs. $\mathrm{H}_{\text {being }}$ tested: $\theta<0$

In this way, $\beta_{\text {the most recent }}=\theta+\beta_{\text {location-specific }}$ and we can rewrite the original regression model and rearrange it as the following:

$\mathrm{P}\left(\right.$ Sequential location dummy=1) $=\beta_{0+}\left(\theta+\beta_{\text {location-specific }}\right) \times N e w n e s$ _tt $_{\text {the most recent }}+$ $\beta_{\text {location-specific } \times N e w n e s s \_l o c a t i o n-s p e c i f i c}+\beta_{\text {control variables }} \times$ Control variables $+\mu$

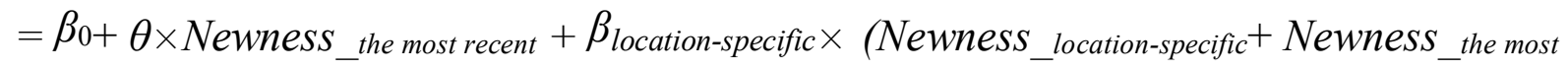

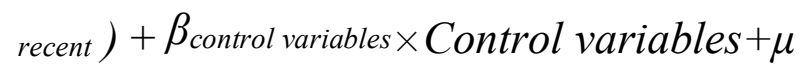

Through estimating the coefficient of $\theta$, we can identify the difference between the newness of the most recent experience and the newness of location-specific experience. In the same vein, we can also test the difference between the newness of the most recent experience and the newness of general experience by using the following model:

$\mathrm{P}($ Counts of OFDI incidents $)=\beta_{0}+\theta \times N e w n e s s \_$the most recent $+\beta_{\text {general }} \times($ Newness_general +

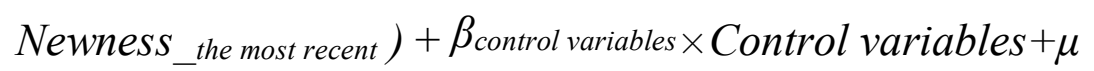

\section{Results}

Table 2 presents the descriptive statistics and a correlation matrix for all variables. As seen in the Table 2, descriptive statistics show that there is no evidence of high correlations 
among all variables so that multicolinearity among all explanatory variables is not a concern. Specifically, the correlations between accumulativeness dimension of experience (i.e. general experience, host-specific experience) and the newness of experience are lower than 0.45 which indicate they are distinctive construct. We present the test results of our hypotheses in Table 3, 4 and 5. In Table 3 and 4 we test our Probit model and NB model respectively. In Table 5, we test our hypotheses $\mathrm{H} 3 \mathrm{a}$ and $\mathrm{H} 3 \mathrm{~b}$. Generally, the values of incremental Log pseudo likelihood, as well as the declines of value of AIC in each table, suggest that the inclusion of the independent variables adds significant statistical power to the baseline model.

Insert Table 2 about here

As is shown in Table 3, the baseline Model 1 includes control variables and a set of year dummies and industry dummies. In Table 3, institutional distance between home and host countries has a significantly negative influence $(p<0.01)$ on sequential location choice. This result indicates that MNCs are less likely to make subsequent location choice which is the same as last entry when institutional distance between home country and host country is large. This is also hold for demographic distance $(p<0.01)$ between home country and host country. Hypothesis 1a predicted that the newness of the most recent experience would be positively associated with the likelihood of choosing the same location as the most recent one. Our results in Model 2 shows that the coefficients are indeed positive and significant $(p<0.05)$, which supports Hypothesis 1a. When we add moderating variables, we also see that outcome expectancy has significantly positive impacts on sequential location choices $(p<0.1)$. The context similarity between the most recent entry country and sequential entry country shows significantly positive effects on the likelihood of entering the same location as the most recent entry $(p<0.01)$, indicating that MNCs are more subject to large institutional difference between the most recent entry and sequential entry. Hypothesis 4a predicted that the relationship between the newness of the most recent experience and the likelihood of 
choosing the same location as the most recent one would be stronger when institutional context between the most recent entry country and sequential entry country is similar. In Model 5, the interaction term for the newness of the most recent experience and context similarity is significantly positive $(p<0.05)$, supporting Hypothesis $4 a$. Finally, the coefficient of interaction term of outcome expectancy of focal entry and the newness of the most recent experience in Model 4 is positive and significant $(p<0.05)$ suggesting that when MNCs have positive outcome expectancy to focal entry, the higher the likelihood of MNCs being subject to persist the same location as recent entry. Therefore, Hypothesis 5 is supported. In Model 6 as the full model, our results remain robust and significant except for the direct impact of recent experience.

Insert Table 3 about here

Table 4 provides our main result of the NB model in which our dependent variable is the counts of the OFDI incidents in focal country. In baseline Model 1, we find that institutional distance $(p<0.05)$ and geographic distance $(p<0.1)$ have significantly negative influence on the number of OFDI incidents while firms with higher state ownership are more likely to make more OFDI incidents in focal country $(p<0.01)$. Our Hypothesis $1 \mathrm{~b}$ and Hypothesis 2 argue that newness of the most recent experience and the newness of general experience are positively associated with the number of OFDI incidents. The significantly positive coefficients $(p<0.01)$ in Model 2 support our expectations. In addition, we find support for Hypothesis $4 \mathrm{~b}$ in model 4 that context similarity between prior entry locations and sequential entry location has a positive moderating effect $(p<0.01)$ on the relationship between the newness of the general experience and the number of OFDI incidents. This supports our argument that general experience decays more slowly and is more likely to be efficiently interpreted and applied when institutional environment between prior entries and sequential entry is similar. 
Insert Table 4 about here

Table 5 reports the comparison tests for Hypothesis $3 \mathrm{a}$ and Hypothesis $3 \mathrm{~b}$. In Model 1, we compare the coefficients of the newness of the most recent experience and the newness of location-specific experience in influencing subsequent location choice. Positive and significant coefficients of Newness_the most recent in Model 1 indicate the coefficient of the newness of the most recent experience is larger than that of the newness of location-specific experience. This result suggests that the most recent experience has a greater influence and decays more slowly than location-specific experience, providing support to our Hypothesis $3 \mathrm{a}$. Model 2 also shows a significant coefficient on Newness_the most recent, suggesting that the coefficient of the newness of the most recent experience is significantly larger than that of the newness of general experience. Thus the result lends support to Hypothesis $3 b$.

Insert Table 5 about here

\section{Robustness analyses}

In addition to the tests noted above, we have performed a set of analyses in order to examine the robustness for our findings. First of all, as we use binary variable to measure outcome expectancy in previous analyses, we then measure it as a continuous variable which is the difference between Tobin's $\mathrm{Q}$ at time $\mathrm{t}$ and Tobin's $\mathrm{Q}$ at time $\mathrm{t}-1$. The result in Table 6 shows the same results as we expected, supporting our Hypothesis 5.

As a second set of robustness checks, we turn our attention to discover what component of context matters as a moderator. In doing so, we replace context similarity by measuring it as institutional scores of six dimensions of institutional environment separately (i.e. voice of accountability, political stability, government effectiveness, regulatory quality, rule of law and control of corruption) from WGI dataset. The result in Table 7 shows that the interactions of 
all different dimensions of context similarities are significantly positive, which confirm the robustness for our Hypothesis 4a.

Further, in Table 8 we also test the marginal effects of the newness of the most recent experience and the newness of the location-specific experience. The result indicates that marginal effects on subsequent location choice of the former one is higher (0.089) than that of later one (0.019), providing robust test for Hypothesis 3a. Similarly, in Table 9, we also find that the marginal effects of the newness of the most recent experience $(0.324)$ on the number of OFDI incidents is higher than the newness of general experience (0.089), showing a strong robustness for empirical results concerning Hypothesis $3 b$.

\section{Insert Table 6,7,8,9 about here}

\section{Discussion and conclusions}

\subsection{Theoretical contributions}

This study offers a new account of how the newness of experience affects the sequential entries from organizational learning perspective and how such a relationship is contingent on context similarity between the most recent entry location and sequential entry location (or between prior entry locations and sequential entry location) and outcome expectancy of MNCs to the focal entry. Based on our empirical results, we find that experience will decay over time and different types of experience decays differently. The findings as a whole reveal that the newness of the most recent experience is more beneficial than the newness of location-specific experience and the newness of general experience in influencing sequential entries. Our results also show that when contexts between the most recent entry country and sequential entry country are institutionally similar or outcome expectancy of focal entry is positive, the relationship between the newness of the most recent experience and sequential location choices is strengthened. Similarly, the relationship between the newness of general 
experience and the number of OFDI incidents will be stronger when context similarity between prior entries and sequential entry is high.

This study makes a contribution to organizational learning research by helping us gain a better understanding of the impact of the time dimension of experience. Reviewing international business studies on experiential learning, we can find that a large body of research focuses on the cumulative effects of experiential learning (Luo, 1999; Casillas \& Moreno-Menéndez, 2013; Lu, et al., 2014; Vermeulen \& Barkema, 2002). Especially in sequential entry research (see a summary in Table 1), prior studies have highlighted the important role of the accumulative dimension of experience in influencing MNC's internationalization (Johanson \& Vahlne,1977; Davidson, 1980; Chang, 1995; Song, 2002). However, experience is often implicitly assumed as stable over time in prior studies. As such, it is worth noting that Nerkar (2003) raises the interesting question "Old is gold?" and argues that recent knowledge may sometimes matter more than distant knowledge in some circumstances. In a similar vein, several studies also suggest that the value of experience may decay over time, and thus the benefits from prior experience may be not hold as before (Argote, et al., 1990; Baum \& Ingram, 1998; Darr, et al., 1995; Madsen \& Desai, 2010). In this study building on the organization learning theory, we add to previous work by purposively turning our attention to the time issue of experience. The evidence of the importance of the newness of experience demonstrated in this study confirms that the newness dimension of the experience plays a critical role in influencing sequential entry strategy. These results are different from those in Nachum and Song (2011) who tested the age of experience as a moderator and find that there is limited depreciation of knowledge in the legal services industry. Our study goes beyond a specific industry and provides a rich research setting to test the role of the newness of experience in a broader set of industries. Our study also highlights a new way to explore the influence of experiential learning on MNC's 
strategic choices and theoretically extends prior studies about the role of experience by emphasizing the importance of depreciation of the learning process, in shaping MNCs' strategic behaviors.

In addition, we extend existing research through examining the different mechanisms of decays for different types of experience in influencing sequential entry. Experience depreciate over time (Nachum \& Song, 2011), but the extent of experience depreciation depends on the types of experience. In our study, we decompose the newness of experience into the newness of the most recent experience, the newness of location-specific experience and the newness of general experience. We predict the influence of newness of the most recent experience is highest than the latter two in influencing both sequential entry and the number of OFDI incidents. Our results support our predictions.

Equally important, our results also complement existing knowledge about contextual influence on experiential learning. The prevailing stream of research in international studies holds an implicit assumption that experience is always welcome when doing business abroad. These studies suggest that firm's prior experience will play a supportive role in reducing the uncertainty of going abroad, no matter the context changes (Belderbos, et al., 2011; Li, Qian, \& Yao, 2014; Xia, et al., 2009). They focus on the direct effects of experience on MNCs' global strategies and there are still limited literatures to define the boundaries for reutilization of experience (Castellaneta \& Zollo, 2014; Hayward, 2002; Nadolska \& Barkema, 2007). For example, although Delios and Beamish (2001b) considered the issue of the transferability of experience by noting that some knowledge gained in one country maybe location-specific, they only explore the direct role of experience on subsidiary performance. Similarly, Perkins (2014) also studies the direct effects of experience in terms of diversity and depth on performance of MNCs. Another research line focuses on the moderating role of experience instead of the boundary conditions of exploiting prior experience (Castellaneta \& Zollo, 2014). 
But exploiting prior experience is just the beginning of the story, and the most important step is identifying the context to efficiently exploit the experience. Thus, to deepen the understanding of organizational learning process cross borders and over time, it is imperative to explore the contingent effect of experiential learning. Muehlfeld, et al. (2012) emphasized the importance of structural similarity in influencing the completion likelihood of acquisition. We add to this line of research and revealed that institutional similarity and outcome expectancy are significant moderators for experience replication.

Our study also provides evidence of institutional environment and outcome expectancy as critical mechanisms influencing the sequential location choices. Prior studies suggest that legitimacy is an important determinant for shaping location choices (Baum, et al., 2000; Belderbos, et al., 2011; Chan, et al., 2006; Jiang et al., 2014). The dominant logic under these studies is that multinational firms can imitate the prior entry decisions of other firms because it is more legitimate for latecomers to make new entry (Guillen, 2002; Jiang, et al., 2014; Martin, Swaminathan, \& Mitchell, 1998). While in our study, we find sequential location choices are not only determined by prior investment decisions of other firms, but also shaped by the context of experiential learning in terms of institutional similarity between host country and home country and outcome expectancy of focal entry. As such, we extend the dominant legitimacy mechanisms through introducing the significant impacts of experiential learning context in explaining the sequential choices of MNCs in overseas investment.

\subsection{Managerial relevance}

The insights generated in this research have several managerial implications. First, we call for paying attention to the time dimension of experience. In general, managers are more inclined to rely on the distant and routinized experience because they feel that even if it may not be the best option, it may be the safest one (Levitt \& March, 1988; Sapienza, Autio, 
George, \& Zahra, 2006; Xia, et al., 2009). This tendency will make shifts between activities difficult when going abroad. However, the environment is getting more complicated and changes very fast nowadays. Especially in global operations, managers are exposed to diverse institutions and thus face higher levels of uncertainty. The benefits of distant knowledge may fail to match the dynamic environment. Based on our theoretical framework and empirical findings, we suggest that managers should be aware of the depreciation of prior knowledge and pay more attention to new experience in order to reduce the interpretation bias and improve the application of prior knowledge. It may be also an alternative for MNCs to break the rigidity of organizations and help them build flexible capabilities and the effective layout of global operations. In addition, our findings also remind international business managers to take contingent factors into consideration because the transferability of knowledge influences the efficiency of exploiting experience (Delios \& Beamish, 1999a). Making foreign investments is much more complicated than domestic investments as firms are more or less uncomfortable when facing institutional difference between countries. Our findings show that managers still need to consider the context applicability in terms of institutional similarity when they exploit prior knowledge. Even when recent experience may benefit sequential entry, managers and consultants still should not overlook the potential threats implied by signals of institutional differences in making internationalization decisions. Instead, they have to flexibly adjust their prior knowledge according to the changes of institutional environment.

\subsection{Limitations and future research}

Although our study offers new insights of the influence of time dimension of experience on MNCs' outward investments, there are still several limitations which may be addressed in future research. First, future research needs to validate the generalizability of our theorizing in other country contexts, such as India, and Africa. In addition, future research can also extend 
our theorizing into developed economies. Second, this paper focuses on two contingent factors for exploiting recent experience. Other contributing factors, such as industry similarity which indicates entering into a similar industry can shared concepts not accessible to those outside the industry (Haunschild, 1994; Laamanen \& Keil, 2008) is also worthwhile to explore in the future. In doing so, we can get a more complete picture on explaining the influence of the newness of experience on firms' foreign entry behaviors. Thirdly, because of data availability, it is very difficult to catch precise evaluation of every OFDI project. Thus the measurement of outcome expectancy of MNCs may be somewhat rough. Future research can apply more refined measurement to test our findings.

\section{References}

Alcácer, J. 2006. Location choices across the value chain: How activity and capability influence collocation. Management Science, 52(10): 1457-1471.

Alcácer, J., \& Chung, W. 2007. Location strategies and knowledge spillovers. Management Science, 53(5): 760-776.

Anand, J., \& Delios, A. 1997. Location specificity and the transferability of downstream assets to foreign subsidiaries. Journal of International Business Studies, 28(3): 579-603.

Ang, S. H., Benischke, M. H., \& Doh, J. P. 2014. The interactions of institutions on foreign market entry mode. Strategic Management Journal, 36(10): 1536-1553.

Argote, L., Beckman, S. L., \& Epple, D. 1990. The persistence and transfer of learning in industrial settings. Management Science, 36(2): 140-154.

Audia, P. G., Locke, E. A., \& Smith, K. G. 2000. The paradox of success: An archival and a laboratory study of strategic persistence following radical environmental change. Academy of Management journal, 43(5): 837-853.

Baloff, N. 1967. Estimating parameters of startup model-An empirical approach, Industry Engineering, 18(4): 248-253.

Barkema, H. G., Bell, J. H., \& Pennings, J. 1996. Foreign entry, cultural barriers and learning. Strategic Management Journal, 17(2): 151-166.

Barkema, H. G., \& Vermeulen, F. 1998. International expansion through start-up or acquisition: A learning perspective. Academy of Management Journal, 41(1): 7-26.

Baum, J. A., \& Ingram, P. 1998. Survival-enhancing learning in the Manhattan hotel industry, 1898-1980. Management Science, 44(7): 996-1016.

Baum, J. A., Li, S. X., \& Usher, J. M. 2000. Making the next move: How experiential and vicarious learning shape the locations of chains' acquisitions. Administrative Science Quarterly, 45(4): 766-801.

Baum, J. A., Rowley, T. J., Shipilov, A. V., \& Chuang, Y.-T. 2005. Dancing with strangers: Aspiration performance and the search for underwriting syndicate partners. Administrative Science Quarterly, 50(4): 
536-575.

Belderbos, R., Olffen, W. V., \& Zou, J. 2011. Generic and specific social learning mechanisms in foreign entry location choice. Strategic Management Journal, 32(12): 1309-1330.

Benkard, C. L. 1999. Learning and forgetting: The dynamics of aircraft production. Yale University, Department of Economics Working Paper, New Haven, CT.

Benito, G. R., \& Gripsrud, G. (1992). The expansion of foreign direct investments: discrete rational location choices or a cultural learning process?. Journal of International Business Studies, 23(3): 461-476.

Berry, H., Guillén, M. F., \& Zhou, N. 2010. An institutional approach to cross-national distance. Journal of International Business Studies, 41(9): 1460-1480.

Beugelsdijk, Sjoerd, R. Maseland, and A. V. Hoorn. 2015. Are Scores on Hofstede's Dimensions of National Culture Stable over Time? A Cohort Analysis. Global Strategy Journal, 5(3):223-240.

Blanc-Brude, F., Cookson, G., Piesse, J., \& Strange, R. 2014. The FDI location decision: Distance and the effects of spatial dependence. International Business Review, 23(4), 797-810.

Boone, T., Ganeshan, R., \& Hicks, R. L. 2008. Learning and knowledge depreciation in professional services. Management Science, 54(7), 1231-1236.

Buckley, P. J., Clegg, L. J., Cross, A. R., Liu, X., Voss, H., \& Zheng, P. 2007. The determinants of Chinese outward foreign direct investment. Journal of International Business Studies, 38(4): 499-518.

Bunderson, J. S., \& Sutcliffe, K. M. 2002. Comparing alternative conceptualizations of functional diversity in management teams: Process and performance effects. Academy of Management Journal, 45(5): 875-893.

Cantwell, J., Dunning, J. H., \& Lundan, S. M. 2010. An evolutionary approach to understanding international business activity: The co-evolution of MNEs and the institutional environment. Journal of International Business Studies, 41(4): 567-586.

Casillas, J. C., \& Moreno-Menéndez, A. M. 2013. Speed of the internationalization process: The role of diversity and depth in experiential learning. Journal of International Business Studies, 45(1): 85-101.

Castellaneta, F., \& Zollo, M. 2014. The dimensions of experiential learning in the management of activity load. Organization Science, 26(1): 140-157.

Caves, R. E., \& Mehra, S. K. 1986. 'Entry of foreign multinationals into US manufacturing industries', in Porter, M. E.(ed.), Competition in Global Industries, Harvard Business School Press, Boston, MA.

Chan, C. M., \& Makino, S. 2007. Legitimacy and multi-level institutional environments: Implications for foreign subsidiary ownership structure. Journal of International Business Studies, 38(4): 621-638.

Chan, C. M., Makino, S., \& Isobe, T. 2006. Interdependent behavior in foreign direct investment: the multi-level effects of prior entry and prior exit on foreign market entry. Journal of International Business Studies, 37(5): 642-665.

Chang, S.-J., \& Park, S. 2005. Types of firms generating network externalities and MNCs' co-location decisions. Strategic Management Journal, 26(7): 595-615.

Chang, S. J. 1995. International expansion strategy of Japanese firms: Capability building through sequential entry. Academy of Management Journal, 38(2): 383-407.

Chang, S. J., \& Rosenzweig, P. M. 1998a. Industry and regional patterns in sequential foreign market entry. Journal of Management Studies, 35(6), 797-821.

Chang, S. J., \& Rosenzweig, P. M. 2001b. The choice of entry mode in sequential foreign direct investment. Strategic Management Journal, 22(8): 747-776.

Chen, G., Crossland, C., \& Luo, S. 2014. Making the same mistake all over again: CEO overconfidence and corporate resistance to corrective feedback. Strategic Management Journal, 36(10): 1513-1535.

Chung, W., \& Song, J. 2004. Sequential investment, firm motives, and agglomeration of Japanese electronics firms in the United States. Journal of Economics \& Management Strategy, 13(3), 539-560.

Crossan, M. M., Lane, H. W., \& White, R. E. 1999. An organizational learning framework: from intuition to institution. Academy of Management Review, 24(3): 522-537.

Cyert, R. M., \& March, J. G. 1963. A behavioral theory of the firm. Englewood Cliffs, NJ, 2.

Darr, E. D., Argote, L., \& Epple, D. 1995. The acquisition, transfer, and depreciation of knowledge in service 
organizations: Productivity in franchises. Management Science, 41(11): 1750-1762.

Davidson, W. H. 1980. The location of foreign direct investment activity: Country characteristics and experience effects. Journal of International Business Studies, 11(2): 9-22.

De Beule, F., \& Duanmu, J.-L. 2012. Locational determinants of internationalization: A firm-level analysis of Chinese and Indian acquisitions. European Management Journal, 30(3): 264-277.

Delios, A., \& Beamish, P. W. 1999a. Ownership strategy of Japanese firms: Transactional, institutional and experience influences. Strategic Management Journal, 20(10): 915-933.

Delios, A., \& Beamish, P. W. 2001b. Survival and profitability: The roles of experience and intangible assets in foreign subsidiary performance. Academy of Management Journal, 44(5): 1028-1038.

Delios, A., \& Henisz, W. I. 2000. Japanese firms' investment strategies in emerging economies. Academy of Management journal, 43(3): 305-323.

Delios, A., \& Henisz, W. J. 2003. Political hazards, experience, and sequential entry strategies: The international expansion of Japanese firms, 1980-1998. Strategic Management Journal, 24(11): 1153-1164.

Delios, A., Wu, Z. J., \& Zhou, N. 2006. A new perspective on ownership identities in China's listed companies. Management and Organization Review, 2(3): 319-343.

Dikova, D., Sahib, P. R., \& van Witteloostuijn, A. 2010. Cross-border acquisition abandonment and completion: The effect of institutional differences and organizational learning in the international business service industry, 1981-2001. Journal of International Business Studies, 41(2): 223-245.

Duanmu, J. L. 2012. Firm heterogeneity and location choice of Chinese multinational enterprises (MNEs). Journal of World Business, 47(1), 64-72.

Eden, L., \& Miller, S. R. 2004. Distance matters: Liability of foreignness, institutional distance and ownership strategy. Advances in International Management, 16: 187-221.

Epple, D., Argote, L., \& Devadas, R. 1991. Organizational learning curves: A method for investigating intra-plant transfer of knowledge acquired through learning by doing. Organization Science, 2(1), 58-70.

Feldman, E. R., \& Montgomery, C. A. 2015. Are incentives without expertise sufficient? Evidence from fortune 500 firms. Strategic Management Journal, 36(1): 113-122.

Gao, G. Y., \& Pan, Y. 2010. The pace of MNEs' sequential entries: Cumulative entry experience and the dynamic process. Journal of International Business Studies, 41(9): 1572-1580.

Gaur, A. S., \& Lu, J. W. 2007. Ownership strategies and survival of foreign subsidiaries: Impacts of institutional distance and experience. Journal of Management, 33(1): 84-110.

Gentry, R. J., \& Shen, W. 2013. The impacts of performance relative to analyst forecasts and analyst coverage on firm R\&D intensity. Strategic Management Journal, 34(1), 121-130.

Gooris, J., \& Peeters, C. 2014. Home-host country distance in offshore governance choices. Journal of International Management, 20(1): 73-86.

Gosling, P., Denizeau, M., \& Oberlé, D. 2006. Denial of responsibility: a new mode of dissonance reduction. Journal of Personality and Social Psychology, 90(5): 722.

Green WH. 2003. Econometric Analysis (5th edn). Upper Saddle River, NJ: Prentice Hall.

Greve, H. R. 2003. A behavioral theory of R\&D expenditures and innovations: Evidence from shipbuilding. Academy of Management Journal, 46(6): 685-702.

Grinblatt, M., \& Keloharju, M. 2009. Sensation seeking, overconfidence, and trading activity. The Journal of Finance, 64(2): 549-578.

Guillén, M. F. 2002. Structural inertia, imitation, and foreign expansion: South Korean firms and business groups in China, 1987-1995. Academy of Management Journal, 45(3): 509-525.

Guillen, M. F. 2002. Structural Inertia, Imitation, and Foreign Expansion: South Korean Firms and Business Groups in China, 1987-1995. Academy of Management Journal, 45(3): 509-525.

Haleblian, J., \& Finkelstein, S. 1999. The influence of organizational acquisition experience on acquisition performance: A behavioral learning perspective. Administrative Science Quarterly, 44(1): 29-56.

Haleblian, J. J., Kim, J.-y. J., \& Rajagopalan, N. 2006. The influence of acquisition experience and performance on acquisition behavior: Evidence from the US commercial banking industry. Academy of 
Management Journal, 49(2): 357-370.

Hampton, M. P., \& Christensen, J. 2002. Offshore pariahs? Small island economies, tax havens, and the re-configuration of global finance. World Development, 30(9): 1657-1673.

Haunschild, P. R. 1994. How much is that company worth?: Interorganizational relationships, uncertainty, and acquisition premiums. Administrative Science Quarterly: 391-411.

Haveman, H. A. 1992. Between a rock and a hard place: Organizational change and performance under conditions of fundamental environmental transformation. Administrative Science Quarterly, 39(3), 37(1): 48-75.

Hayward, M. L. 2002. When do firms learn from their acquisition experience? Evidence from 1990 to 1995. Strategic Management Journal, 23(1): 21-39.

Heeley, M. B., \& Jacobson, R. 2008. The recency of technological inputs and financial performance. Strategic Management Journal, 29(7): 723-744.

Heimeriks, K. H. 2010. Confident or competent? How to avoid superstitious learning in alliance portfolios. Long Range Planning, 43(1): 57-84.

Henderson, J., \& Cool, K. 2003. Learning to time capacity expansions: An empirical analysis of the worldwide petrochemical industry, 1975-95. Strategic Management Journal, 24(5), 393-413.

Henisz, W. J., \& Delios, A. 2001. Uncertainty, Imitation, and Plant Location: Japanese Multinational Corporations, 1990-1996. Administrative Science Quarterly, 46(3): 443-475.

Henisz, W. J., \& Macher, J. T. 2004. Firm-and country-level trade-offs and contingencies in the evaluation of foreign investment: The semiconductor industry, 1994-2002. Organization Science, 15(5): 537-554.

Hernández, V., \& Nieto, M. J. 2015. The effect of the magnitude and direction of institutional distance on the choice of international entry modes. Journal of World Business, 50(1): 122-132.

Ho, M. H. W., \& Wang, F. 2015. Unpacking knowledge transfer and learning paradoxes in international strategic alliances: Contextual differences matter. International Business Review, 24(2), 287-297.

Hofstede, G. 1980. Culture's consequences: International differences in work-related value. Beverly Hill, CA: Sage Publications.

Hogarth, R. M., \& Einhorn, H. J. 1992. Order effects in belief updating: The belief-adjustment model. Cognitive Psychology, 24(1): 1-55.

Holan, P. M. d., \& Phillips, N. 2004. Remembrance of things past? The dynamics of organizational forgetting. Management Science, 50(11): 1603-1613.

Holburn, G. L., \& Zelner, B. A. 2010. Political capabilities, policy risk, and international investment strategy: Evidence from the global electric power generation industry. Strategic Management Journal, 31(12): 1290-1315.

Hotho, J. J., Lyles, M. A., \& Easterby-Smith, M. 2015. The mutual impact of global strategy and organizational learning: current themes and future directions. Global Strategy Journal, 5(2): 85-112.

Huber, G. P. 1991. Organizational learning: The contributing processes and the literatures. Organization Science, 2(1): 88-115.

Huett P, Baum M, Schwens C, Kabst. R. 2014. Foreign direct investment location choice of small-and medium-sized enterprises: The risk of value erosion of firm-specific resources. International Business Review,, 23(5): 952-965.

Huynh, W., Mallik, G., \& Hettihewa, S. 2006. The impact of macroeconomic variables, demographic structure and compulsory superannuation on share prices: The case of Australia. Journal of International Business Studies, 37(5), 687-698.

Jiang, G. F., Holburn, G. L., \& Beamish, P. W. 2014. The Impact of Vicarious Experience on Foreign Location Strategy. Journal of International Management, 20(3): 345-358.

Johanson, J., \& Vahlne, J.-E. 1977. The internationalization process of the firm-a model of knowledge development and increasing foreign market commitments. Journal of International Business Studies, 8(1): 23-32.

Johanson, J., \& Vahlne, J.-E. 2009. The Uppsala internationalization process model revisited: From liability of 
foreignness to liability of outsidership. Journal of International Business Studies, 40(9): 1411-1431.

Kato, T., \& Long, C. 2006. Executive turnover and firm performance in China. The American Economic Review, 96(2): 363-367.

Kaufmann, D., Kraay, A., \& Mastruzzi, M. 2005. Governance matters IV: governance indicators for 1996-2004. World Bank Policy Research Working Paper (3630).

Kim, J.-Y., Kim, J.-Y., \& Miner, A. S. 2009. Organizational learning from extreme performance experience: The impact of success and recovery experience. Organization Science, 20(6): 958-978.

Kim, W. C., \& Hwang, P. 1992. Global strategy and multinationals' entry mode choice. Journal of International Business Studies, 23(1): 29-53.

Kogut, B. 1983. Foreipn Direct Investment as a Sequential Process. In C.P. Kindelberger \&D. Andretsch (Eds.), The multinational corporation in the 1980s. Cambridge, MA: MIT Press.

Kogut, B., \& Chang, S. J. 1991. Technological capabilities and Japanese foreign direct investment in the United States. The Review of Economics and Statistics, 73(3): 401-413.

Kogut, B., \& Chang, S. J. 1996. Platform investments and volatile exchange rates: Direct investment in the US by Japanese electronic companies. The Review of Economics and Statistics, 78(2): 221-231.

Kostova, T. 1999. Transnational transfer of strategic organizational practices: A contextual perspective. Academy of Management Review, 24(2): 308-324.

Laamanen, T., \& Keil, T. 2008. Performance of serial acquirers: toward an acquisition program perspective. Strategic Management Journal, 29(6): 663-672.

Levinthal, D. A., \& March, J. G. 1993. The myopia of learning. Strategic Management Journal, 14(S2): 95-112.

Levitt, B., \& March, J. G. 1988. Organizational learning. Annual review of sociology, 14(1): 319-340.

Li, J., Qian, C., \& Yao, F. K. 2014. Confidence in learning: Inter-and intraorganizational learning in foreign market entry decisions. Strategic Management Journal, 36(6): 918-929.

Li, J., Yang, J. Y., \& Yue, D. R. 2007. Identity, Community, And Audience: How Wholly Owned Foreign Subsidiaries Gain Legitimacy In China. Academy of Management journal, 50(1): 175-190.

Li, P. Y., \& Meyer, K. E. 2009. Contextualizing experience effects in international business: A study of ownership strategies. Journal of World Business, 44(4), 370-382.

Lu, J., Liu, X., Wright, M., \& Filatotchev, I. 2014. International experience and FDI location choices of Chinese firms: The moderating effects of home country government support and host country institutions. Journal of International Business Studies, 45(4): 428-449.

Lu, J. W., \& Xu, D. 2006. Growth and survival of international joint ventures: An external-internal legitimacy perspective. Journal of Management, 32(3): 426-448.

Lubatkin, M., Calori, R., Very, P., \& Veiga, J. F. 1998. Managing mergers across borders: A two-nation exploration of a nationally bound administrative heritage. Organization Science, 9(6): 670-684.

Luo, Y. 1999. Time-based Experience and International Expansion: The Case of an Emerging Economy. Journal of Management Studies, 36(4): 505-534.

Luo, Y., Xue, Q., \& Han, B. 2010. How emerging market governments promote outward FDI: Experience from China. Journal of World Business, 45(1): 68-79.

Lyer, D. N., \& Miller, K. D. 2008. Performance feedback, slack, and the timing of acquisitions. Academy of Management Journal, 51(4), 808-822.

Madsen, P. M., \& Desai, V. 2010. Failing to learn? The effects of failure and success on organizational learning in the global orbital launch vehicle industry. Academy of Management Journal, 53(3): 451-476.

Makino, S., \& Tsang, E. W. 2011. Historical ties and foreign direct investment: An exploratory study. Journal of International Business Studies, 42(4), 545-557.

Martin, X., Swaminathan, A., \& Mitchell, W. 1998. Organizational evolution in the interorganizational environment: Incentives and constraints on international expansion strategy. Administrative Science Quarterly, 43(3): 566-601.

Miller, D., \& Chen, M.-J. 1994. Sources and consequences of competitive inertia: A study of the US airline 
industry. Administrative Science Quarterly, 39(1): 1-23.

Miller, D., Xu, X., \& Mehrotra, V. 2015. When is human capital a valuable resource? The performance effects of Ivy league selection among celebrated CEOs. Strategic Management Journal, 36(6): 930-944.

Morck, R., Yeung, B., \& Zhao, M. 2008. Perspectives on China's outward foreign direct investment. Journal of International Business Studies, 39(3): 337-350.

Muehlfeld, K., Rao Sahib, P., \& Van Witteloostuijn, A. 2012. A contextual theory of organizational learning from failures and successes: A study of acquisition completion in the global newspaper industry, 1981-2008. Strategic Management Journal, 33(8): 938-964.

Nachum L, Song S. 2011.The MNE as a portfolio: Interdependencies in MNE growth trajectory. Journal of International Business Studies, 2011, 42(3): 381-405.

Nadolska, A., \& Barkema, H. G. 2007. Learning to internationalise: the pace and success of foreign acquisitions. Journal of International Business Studies, 38(7): 1170-1186.

Nelson, R. R., \& Winter, S. G. 2009. An evolutionary theory of economic change: Harvard University Press.

Nerkar, A. 2003. Old is gold? The value of temporal exploration in the creation of new knowledge. Management Science, 49(2): 211-229.

Ojala, A. 2015. Geographic, cultural, and psychic distance to foreign markets in the context of small and new ventures. International Business Review, 24(5), pp.825-835.

Perkins, S. E. 2014. When does prior experience pay? Institutional experience and the multinational corporation. Administrative Science Quarterly, 59(1): 145-181.

Petersen, B., Pedersen, T., \& Lyles, M. A. 2008. Closing knowledge gaps in foreign markets. Journal of International Business Studies, 39(7): 1097-1113.

Quer, D., Claver, E., \& Rienda, L. 2012. Political risk, cultural distance, and outward foreign direct investment: Empirical evidence from large Chinese firms. Asia Pacific Journal of Management, 29(4), 1089-1104.

Ramasamy, B., Yeung, M., \& Laforet, S. 2012. China's outward foreign direct investment: Location choice and firm ownership. Journal of World Business, 47(1): 17-25.

Sørensen, J. B., \& Stuart, T. E. 2000. Aging, obsolescence, and organizational innovation. Administrative Science Quarterly, 45(1): 81-112.

Salomon, R., \& Wu, Z. 2012. Institutional distance and local isomorphism strategy. Journal of International Business Studies, 43(4): 343-367.

Sapienza, H. J., Autio, E., George, G., \& Zahra, S. A. 2006. A capabilities perspective on the effects of early internationalization on firm survival and growth. Academy of Management Review, 31(4): 914-933.

Schwab, A., \& Miner, A. S. 2008. Learning in hybrid-project systems: The effects of project performance on repeated collaboration. Academy of Management Journal, 51(6): 1117-1149.

Sethi, D., \& Guisinger, S. 2002. Liability of foreignness to competitive advantage: How multinational enterprises cope with the international business environment. Journal of International Management, 8(3): 223-240.

Shi, W.S., Sun, S.L., Pinkham, B.C. and Peng, M.W., 2014. Domestic alliance network to attract foreign partners: Evidence from international joint ventures in China. Journal of International Business Studies, 45(3): 338-362.

Shleifer, A., \& Vishny, R. W. 1997. A survey of corporate governance. The Journal of Finance, 52(2): 737-783.

Siegel, J. I., \& Larson, B. Z. 2009. Labor market institutions and global strategic adaptation: Evidence from Lincoln Electric. Management Science, 55(9): 1527-1546.

Slangen, A. H., \& Hennart, J.-F. 2008. Do multinationals really prefer to enter culturally distant countries through greenfields rather than through acquisitions? The role of parent experience and subsidiary autonomy. Journal of International Business Studies, 39(3): 472-490.

Song, J. 2002. Firm capabilities and technology ladders: Sequential foreign direct investments of Japanese electronics firms in East Asia. Strategic Management Journal, 23(3), 191-210. 
Vermeulen, F., \& Barkema, H. 2002. Pace, rhythm, and scope: Process dependence in building a profitable multinational corporation. Strategic Management Journal, 23(7): 637-653.

Villalonga, B., \& Amit, R. 2006. How do family ownership, control and management affect firm value? Journal of Financial Economics, 80(2): 385-417.

Walsh J P, Ungson G R. 1991. Organizational memory. Academy of Management Review, 16(1): 57-91.

Wang, C., Hong, J., Kafouros, M., \& Wright, M. 2012. Exploring the role of government involvement in outward FDI from emerging economies. Journal of International Business Studies, 43(7): 655-676.

Wernerfelt, B., \& Montgomery, C. A. 1988. Tobin's q and the importance of focus in firm performance. The American Economic Review, 246-250.

Wowak, A. J., \& Hambrick, D. C. 2010. A model of person-pay interaction: how executives vary in their responses to compensation arrangements. Strategic Management Journal, 31(8): 803-821.

Xia, J., Boal, K., \& Delios, A. 2009. When experience meets national institutional environmental change: foreign entry attempts of US firms in the Central and Eastern European region. Strategic Management Journal, 30(12): 1286-1309.

Xia, J., Ma, X., Lu, J. W., \& Yiu, D. W. 2014. Outward foreign direct investment by emerging market firms: a resource dependence logic. Strategic Management Journal, 35(9): 1343-1363.

Xie, Q., 2014. CEO tenure and ownership mode choice of Chinese firms: The moderating roles of managerial discretion. International Business Review,23(5), pp.910-919.

Xu, D., Pan, Y., \& Beamish, P. W. 2004. The effect of regulative and normative distances on MNE ownership and expatriate strategies. Management International Review, 44(3): 285-307.

$\mathrm{Xu}$, D., \& Shenkar, O. 2002. Note: Institutional distance and the multinational enterprise. Academy of Management Review, 27(4): 608-618.

Zeng, Y., Shenkar, O., Lee, S.-H., \& Song, S. 2013. Cultural differences, MNE learning abilities, and the effect of experience on subsidiary mortality in a dissimilar culture: Evidence from Korean MNEs. Journal of International Business Studies, 44(1): 42-65.

Zhang, Y., Zhang, Z., \& Liu, Z. 2007. Choice of entry modes in sequential FDI in an emerging economy. Management Decision, 45(4): 749-772. 
Table 1 Summery of existing studies about sequential entry

\begin{tabular}{|c|c|c|c|}
\hline Articles & Main arguments & $\begin{array}{l}\text { Dimension of } \\
\text { experience }\end{array}$ & Measurements of experience \\
\hline $\begin{array}{l}\text { Johanson \& Vahlne } \\
\text { (1977) }\end{array}$ & $\begin{array}{l}\text { - Foreign market expansion is based on gradual learning and the development of market } \\
\text { knowledge. } \\
\text { - } \quad \text { The process of internationalization is sequential build-up commitment over time. }\end{array}$ & Experience depth & - \\
\hline Davidson (1980) & $\begin{array}{l}\text { - Prior experience in a host country is found to increase the firm's priority for projects in that } \\
\text { country relative to other investment options. } \\
\text { Inexperienced firms exhibit greater preference for near, similar markets than firms with } \\
\text { international operating experience. }\end{array}$ & Experience depth & $\begin{array}{l}\text { The percentage of cases in } \\
\text { which investment in an } \\
\text { industry was initiated in one } \\
\text { country before others. }\end{array}$ \\
\hline $\begin{array}{l}\text { Benito and Gripsrud } \\
\text { (1992) }\end{array}$ & $\begin{array}{l}\text { - The first FDIs undertaken are made in countries that are culturally closer to home country } \\
\text { than later FDIs. } \\
\text { The cultural distance to the country where an FDI is made will increase with the number of } \\
\text { FDIs previously undertaken by a given company. }\end{array}$ & Experience depth & $\begin{array}{l}\text { Accumulated count of prior } \\
\text { entries }\end{array}$ \\
\hline Chang (1995) & $\begin{array}{l}\text { - Firms will sequentially enter a foreign market, moving from their core business to noncore } \\
\text { business } \\
\text { As firms accumulate investments in a foreign market, they become likely to invest further } \\
\text { in that market. }\end{array}$ & Experience depth & $\begin{array}{l}\text { Accumulated count of prior } \\
\text { entries }\end{array}$ \\
\hline Chang (1998a) & $\begin{array}{l}\text { - } \quad \text { Firms prior entries are important for sequential market entry regardless of region of origin. } \\
\text { - } \quad \text { Sequential entry was strongly shaped by industry factors. }\end{array}$ & Experience depth & $\begin{array}{l}\text { Number of the lines of } \\
\text { business which previous } \\
\text { entered. }\end{array}$ \\
\hline $\begin{array}{l}\text { Chang \& } \\
\text { Rosenzweig (2001b) }\end{array}$ & $\begin{array}{l}\text { - International experience is very important for firms making foreign investment, as firms } \\
\text { learn from early entries and adapt the modes of subsequent ones. }\end{array}$ & Experience depth & $\begin{array}{l}\text { The ratio of sales in the } \\
\text { North American region to } \\
\text { total sales, measured at the } \\
\text { time } t-1 \text { of investment. }\end{array}$ \\
\hline
\end{tabular}




\begin{tabular}{|c|c|c|c|}
\hline Articles & - $\quad$ Main arguments & $\begin{array}{l}\text { Dimension of } \\
\text { experience }\end{array}$ & Measurements of experience \\
\hline Song (2002) & $\begin{array}{l}\text { - Local capabilities (including overall local experiences, local sourcing capabilities, local } \\
\text { managerial capabilities, local manufacturing and engineering capabilities) have great } \\
\text { importance to sequential foreign investment decisions. }\end{array}$ & Experience depth & $\begin{array}{l}\text { Time duration of the } \\
\text { duration of local operation }\end{array}$ \\
\hline $\begin{array}{l}\text { Delios \& } \\
\text { Henisz(2003) }\end{array}$ & $\begin{array}{l}\text { - Firms with high level of international experience were less sensitive to the deterring effect } \\
\text { of political hazards in making sequential entry. }\end{array}$ & Experience depth & $\begin{array}{l}\text { Logarithm of a firm's years } \\
\text { of experience in the } \\
\text { operation of subsidiaries }\end{array}$ \\
\hline $\begin{array}{l}\text { Chung \& Song } \\
\text { (2004) }\end{array}$ & - $\quad$ Firms often invest multiple times within the same host country. & Experience depth & count of prior investments \\
\hline $\begin{array}{l}\text { Zhang, Zhang \& Liu } \\
\text { (2007) }\end{array}$ & $\begin{array}{l}\text { - Firms seeking a global market in emerging economies prefer joint venture in earlier entries, } \\
\text { whereas they prefer to select greenfield investments or acquisitions in sequential entries } \\
\text { when they get more international experience. }\end{array}$ & Experience depth & $\begin{array}{l}\text { Case study and country-level } \\
\text { data }\end{array}$ \\
\hline $\begin{array}{l}\text { Nachum \& Song } \\
\text { (2011) }\end{array}$ & $\begin{array}{l}\text { - MNEs as a portfolio of interdependent sub-units and evolve in directions that follow from } \\
\text { their past. } \\
\text { The greater the fit of location to an MNE's portfolio, the smaller the likelihood of entry } \\
\text { into this location. } \\
\text { - The older MNEs' portfolios the less likely they are to enter locations with lower fit. }\end{array}$ & $\begin{array}{l}\text { Experience } \\
\text { diversity } \\
\text { Age of experience }\end{array}$ & $\begin{array}{l}\text { Standard deviation of the } \\
\text { characteristics of the } \\
\text { countries constituting the } \\
\text { portfolio. } \\
\text { The combined years since } \\
\text { entry to all the countries in } \\
\text { the portfolio. }\end{array}$ \\
\hline $\begin{array}{l}\text { Lu, Liu, Wright \& } \\
\text { Filatotchev (2014) }\end{array}$ & $\begin{array}{l}\text { - Host-specific experience encourages firms to select the country for further new } \\
\text { investments. } \\
\text { - Home government support and host country negatively moderate the relationship between } \\
\text { international experience and subsequent location choice. }\end{array}$ & Experience depth & $\begin{array}{l}\text { The logarithm of the number } \\
\text { of prior FDI entries into } \\
\text { particular host country. }\end{array}$ \\
\hline
\end{tabular}


Table 2 Descriptive statistics and correlation matrix.

\begin{tabular}{|c|c|c|c|c|c|c|c|c|c|c|c|}
\hline Variables & Mean & Std. Dev. & 1 & 2 & 3 & 4 & 5 & 6 & 7 & 8 & 9 \\
\hline 1.Subsequent location choice & 0.30 & 0.46 & 1 & & & & & & & & \\
\hline 2.The number of OFDI incidents & 1.92 & 2.54 & 0.399 & 1 & & & & & & & \\
\hline 4.Newness_location-specific & 7.04 & 1.62 & 0.350 & 0.239 & 0.075 & 1 & & & & & \\
\hline 5.Newness_general & 9.50 & 1.24 & -0.011 & 0.304 & -0.283 & 0.289 & 1 & & & & \\
\hline $\begin{array}{l}\text { 8.Context similarity (prior entries vs. focal } \\
\text { entry) }\end{array}$ & 0.85 & 0.14 & 0.179 & 0.247 & 0.061 & 0.273 & -0.032 & -0.110 & 0.440 & 1 & \\
\hline 9.Location importance of host country & 0.03 & 0.04 & 0.053 & 0.118 & -0.009 & 0.054 & 0.046 & 0.166 & -0.050 & -0.061 & 1 \\
\hline 13.Demographic distance & 6.40 & 5.00 & -0.190 & -0.187 & 0.086 & -0.121 & -0.104 & -0.183 & 0.034 & 0.122 & -0.337 \\
\hline 14.Geographic distance & 8.75 & 0.54 & 0.021 & -0.095 & 0.164 & 0.009 & -0.120 & -0.059 & -0.004 & -0.022 & -0.248 \\
\hline 15.General experience & 5.93 & 8.95 & 0.017 & 0.209 & -0.084 & 0.144 & 0.452 & 0.049 & -0.032 & -0.029 & 0.022 \\
\hline 16.Host-specific experience & 0.97 & 2.61 & 0.308 & 0.143 & -0.080 & 0.390 & 0.388 & 0.009 & 0.252 & 0.242 & 0.097 \\
\hline 17.State ownership & 0.21 & 0.24 & 0.028 & -0.049 & -0.044 & -0.052 & 0.158 & 0.037 & -0.070 & -0.022 & 0.007 \\
\hline 18.OFDI flow & 15.13 & 4.10 & 0.059 & 0.080 & -0.225 & -0.011 & -0.002 & 0.040 & 0.001 & 0.100 & 0.022 \\
\hline 19.Firm age & 15.23 & 4.24 & 0.031 & 0.184 & -0.188 & 0.102 & 0.312 & -0.049 & 0.024 & -0.003 & 0.011 \\
\hline 20.Firm size & 22.65 & 1.21 & -0.073 & -0.078 & -0.033 & -0.026 & 0.297 & 0.056 & -0.133 & 0.009 & 0.029 \\
\hline
\end{tabular}


Table 2 continued

\begin{tabular}{|c|c|c|c|c|c|c|c|c|c|c|c|}
\hline & 10 & 11 & 12 & 13 & 14 & 15 & 16 & 17 & 18 & 19 & 20 \\
\hline 11.Cultural distance & 0.045 & 1 & & & & & & & & & \\
\hline 13.Demographic distance & -0.162 & -0.258 & -0.215 & 1 & & & & & & & \\
\hline 14.Geographic distance & -0.280 & 0.369 & -0.136 & 0.087 & 1 & & & & & & \\
\hline 16.Host-specific experience & -0.214 & -0.045 & 0.071 & -0.174 & -0.091 & 0.350 & 1 & & & & \\
\hline 17.State ownership & 0.126 & 0.014 & 0.025 & -0.130 & -0.092 & -0.030 & -0.038 & 1 & & & \\
\hline 18.OFDI flow & 0.034 & 0.002 & 0.083 & -0.096 & -0.008 & -0.209 & 0.084 & 0.082 & 1 & & \\
\hline 19.Firm age & 0.015 & -0.057 & 0.191 & -0.133 & -0.085 & -0.007 & 0.192 & 0.117 & 0.101 & 1 & \\
\hline 20.Firm size & 0.065 & 0.001 & -0.037 & -0.028 & 0.020 & 0.381 & 0.004 & 0.374 & -0.005 & 0.121 & 1 \\
\hline
\end{tabular}

otes: Dummy variables for industry and year are not included. Correlations $>0.1$ or $<-0.1$ are significant at the 0.05 level (two-tail test) 
Table 3 Probit model results

\begin{tabular}{|c|c|c|c|c|c|c|}
\hline & \multicolumn{5}{|c|}{ Subsequent location choice } & \multirow[b]{2}{*}{ Model 6} \\
\hline & Model 1 & Model 2 & Model 3 & Model 4 & Model 5 & \\
\hline \multirow{2}{*}{$\begin{array}{l}\text { Location importance of host } \\
\text { country }\end{array}$} & 0.429 & 0.531 & 0.396 & 0.259 & 0.055 & -0.201 \\
\hline & $(2.594)$ & $(2.404)$ & $(2.551)$ & $(2.610)$ & $(2.625)$ & $(2.755)$ \\
\hline \multirow[t]{2}{*}{ Institutional distance } & $-0.332^{* * *}$ & $-0.298^{* * *}$ & $-0.243^{* *}$ & $-0.255^{* *}$ & $-0.242^{* *}$ & $-0.260^{* *}$ \\
\hline & $(0.098)$ & $(0.098)$ & $(0.100)$ & $(0.101)$ & $(0.100)$ & $(0.103)$ \\
\hline \multirow[t]{2}{*}{ Cultural distance } & -0.004 & 0.003 & -0.003 & -0.001 & -0.006 & -0.004 \\
\hline & $(0.016)$ & $(0.016)$ & $(0.017)$ & $(0.019)$ & $(0.016)$ & $(0.017)$ \\
\hline \multirow[t]{2}{*}{ Administrative distance } & -0.000 & -0.001 & -0.002 & -0.002 & -0.002 & -0.002 \\
\hline & $(0.006)$ & $(0.006)$ & $(0.007)$ & $(0.007)$ & $(0.006)$ & $(0.006)$ \\
\hline \multirow[t]{2}{*}{ Demographic distance } & $-0.059^{* * *}$ & $-0.058^{* * *}$ & $-0.059^{* * *}$ & $-0.058^{* * *}$ & $-0.060^{* * *}$ & $-0.059^{* * *}$ \\
\hline & $(0.017)$ & $(0.017)$ & $(0.018)$ & $(0.018)$ & $(0.018)$ & $(0.018)$ \\
\hline \multirow[t]{2}{*}{ Geographic distance } & 0.067 & -0.043 & -0.047 & -0.102 & -0.025 & -0.089 \\
\hline & $(0.159)$ & $(0.169)$ & $(0.183)$ & $(0.177)$ & $(0.181)$ & $(0.181)$ \\
\hline \multirow[t]{2}{*}{ General experience } & -0.006 & 0.001 & 0.005 & 0.006 & 0.005 & 0.007 \\
\hline & $(0.011)$ & $(0.012)$ & $(0.010)$ & $(0.012)$ & $(0.010)$ & $(0.010)$ \\
\hline \multirow[t]{2}{*}{ Host-specific experience } & 0.173 & 0.092 & 0.042 & 0.046 & 0.063 & 0.075 \\
\hline & $(0.110)$ & $(0.092)$ & $(0.076)$ & $(0.062)$ & $(0.083)$ & $(0.081)$ \\
\hline \multirow[t]{2}{*}{ State-ownership share } & 0.284 & 0.433 & 0.432 & 0.347 & 0.258 & 0.105 \\
\hline & $(0.500)$ & $(0.511)$ & $(0.513)$ & $(0.470)$ & $(0.506)$ & $(0.508)$ \\
\hline \multirow[t]{2}{*}{ OFDI flow } & 0.002 & 0.021 & 0.023 & 0.025 & 0.021 & 0.023 \\
\hline & $(0.019)$ & $(0.017)$ & $(0.017)$ & $(0.018)$ & $(0.019)$ & $(0.020)$ \\
\hline \multirow[t]{2}{*}{ Firm age } & -0.006 & -0.000 & 0.001 & -0.003 & -0.000 & -0.006 \\
\hline & $(0.020)$ & $(0.021)$ & $(0.022)$ & $(0.020)$ & $(0.023)$ & $(0.024)$ \\
\hline \multirow[t]{2}{*}{ Firm size } & -0.141 & $-0.150^{*}$ & -0.134 & -0.105 & -0.142 & -0.108 \\
\hline & $(0.086)$ & $(0.090)$ & $(0.097)$ & $(0.081)$ & $(0.096)$ & $(0.098)$ \\
\hline \multirow[t]{2}{*}{ Newness_the most recent } & & $0.329^{* *}$ & $0.319^{* * *}$ & 0.027 & $0.328^{* *}$ & -0.071 \\
\hline & & $(0.144)$ & $(0.149)$ & $(0.189)$ & $(0.163)$ & $(0.176)$ \\
\hline \multirow[t]{2}{*}{ Newness_location-specific } & & $0.069^{*}$ & $0.074^{*}$ & $0.068^{*}$ & $0.068^{*}$ & 0.059 \\
\hline & & $(0.041)$ & $(0.040)$ & $(0.038)$ & $(0.040)$ & $(0.039)$ \\
\hline \multirow[t]{2}{*}{ Outcome expectancy } & & & $0.317^{*}$ & $0.311^{*}$ & $0.337^{*}$ & $0.344^{* *}$ \\
\hline & & & $(0.174)$ & $(0.161)$ & $(0.179)$ & $(0.175)$ \\
\hline Context similarity & & & $1.748^{* * *}$ & $1.762^{* * *}$ & $1.772^{* * * *}$ & $1.806^{* * *}$ \\
\hline \multicolumn{7}{|l|}{ entry) } \\
\hline Newness_the most recent* & & & & $0.524^{* *}$ & & $0.729^{* *}$ \\
\hline Outcome expectancy & & & & $(0.254)$ & & $(0.301)$ \\
\hline Newness_the most recent* & & & & & $1.255^{* *}$ & $1.660^{* * *}$ \\
\hline Context similarity & & & & & $(0.567)$ & $(0.610)$ \\
\hline \multicolumn{7}{|l|}{$\begin{array}{l}\text { (the most recent entry vs. focal } \\
\text { entry) }\end{array}$} \\
\hline Industry dummy & Yes & Yes & Yes & Yes & Yes & Yes \\
\hline Year dummy & Yes & Yes & Yes & Yes & Yes & Yes \\
\hline \multirow[t]{2}{*}{ Constant } & 0.563 & 0.450 & 0.154 & 0.115 & 0.144 & 0.080 \\
\hline & $(0.680)$ & $(0.742)$ & $(0.759)$ & $(0.626)$ & $(0.790)$ & $(0.807)$ \\
\hline Observations & 410 & 410 & 410 & 410 & 410 & 410 \\
\hline Log pseudo likelihood & -203.703 & -197.296 & -184.696 & -182.211 & -181.425 & -177.094 \\
\hline Pseudo $\mathrm{R}^{2}$ & 0.189 & 0.215 & 0.265 & 0.275 & 0.278 & 0.295 \\
\hline AIC & 461.407 & 452.592 & 431.392 & 430.423 & 426.851 & 420.188 \\
\hline
\end{tabular}

Notes: Robust standard errors in parentheses

${ }^{*} p<0.1,{ }^{* *} p<0.05,{ }^{* * *} p<0.01$ 
Table 4 Negative binominal model: The number of OFDI incidents

\begin{tabular}{|c|c|c|c|c|}
\hline \multicolumn{5}{|c|}{ The number of OFDI incidents } \\
\hline & model 1 & model 2 & model 3 & model 4 \\
\hline \multirow{2}{*}{$\begin{array}{l}\text { Location importance of host } \\
\text { country }\end{array}$} & 0.519 & 0.180 & 0.146 & 0.306 \\
\hline & $(1.539)$ & $(1.326)$ & $(1.324)$ & $(1.324)$ \\
\hline \multirow[t]{2}{*}{ Institutional distance } & $-0.178^{* *}$ & $-0.162^{* * *}$ & $-0.147^{* * *}$ & $-0.143^{* * *}$ \\
\hline & $(0.075)$ & $(0.042)$ & $(0.043)$ & $(0.043)$ \\
\hline \multirow[t]{2}{*}{ Cultural distance } & -0.013 & -0.007 & -0.007 & -0.007 \\
\hline & $(0.012)$ & $(0.010)$ & $(0.010)$ & $(0.010)$ \\
\hline \multirow[t]{2}{*}{ Administrative distance } & 0.006 & $0.005^{*}$ & $0.005^{*}$ & $0.005^{*}$ \\
\hline & $(0.005)$ & $(0.003)$ & $(0.003)$ & $(0.003)$ \\
\hline \multirow[t]{2}{*}{ Demographic distance } & -0.003 & -0.002 & -0.003 & -0.003 \\
\hline & $(0.010)$ & $(0.009)$ & $(0.009)$ & $(0.009)$ \\
\hline \multirow[t]{2}{*}{ Geographic distance } & $-0.159^{*}$ & $-0.147^{*}$ & $-0.150^{*}$ & -0.139 \\
\hline & $(0.087)$ & $(0.085)$ & $(0.086)$ & $(0.086)$ \\
\hline \multirow[t]{2}{*}{ General experience } & -0.002 & -0.010 & -0.008 & -0.009 \\
\hline & $(0.005)$ & $(0.006)$ & $(0.006)$ & $(0.006)$ \\
\hline \multirow[t]{2}{*}{ Host-specific experience } & -0.003 & -0.018 & -0.015 & -0.015 \\
\hline & $(0.022)$ & $(0.019)$ & $(0.019)$ & $(0.019)$ \\
\hline \multirow[t]{2}{*}{ State-ownership share } & $1.320^{* * *}$ & $1.214^{* * *}$ & $1.192^{* * *}$ & $1.186^{* * *}$ \\
\hline & $(0.435)$ & $(0.223)$ & $(0.224)$ & $(0.224)$ \\
\hline \multirow[t]{2}{*}{ OFDI flow } & 0.003 & 0.004 & 0.004 & 0.005 \\
\hline & $(0.011)$ & $(0.009)$ & $(0.009)$ & $(0.010)$ \\
\hline \multirow[t]{2}{*}{ Firm age } & $0.023^{* *}$ & 0.008 & 0.008 & 0.010 \\
\hline & $(0.011)$ & $(0.011)$ & $(0.011)$ & $(0.011)$ \\
\hline \multirow[t]{2}{*}{ Firm size } & 0.001 & -0.030 & -0.032 & -0.035 \\
\hline & $(0.052)$ & $(0.042)$ & $(0.042)$ & $(0.042)$ \\
\hline \multirow[t]{2}{*}{ Newness_location-specific } & $0.076^{* * *}$ & $0.144^{* * *}$ & $0.130^{* * *}$ & $0.127^{* * *}$ \\
\hline & $(0.020)$ & $(0.030)$ & $(0.031)$ & $(0.031)$ \\
\hline \multirow[t]{2}{*}{ Newness_the most recent } & & $0.159^{* * *}$ & $0.147^{* *}$ & $0.148^{* *}$ \\
\hline & & $(0.061)$ & $(0.061)$ & $(0.062)$ \\
\hline \multirow[t]{2}{*}{ Newness_general } & & $0.044^{* * *}$ & $0.040^{* * *}$ & $0.040^{* * *}$ \\
\hline & & $(0.013)$ & $(0.013)$ & $(0.013)$ \\
\hline \multirow{2}{*}{$\begin{array}{l}\text { Context similarity (prior } \\
\text { entries vs. focal entry) }\end{array}$} & & & 0.227 & 0.223 \\
\hline & & & $(0.145)$ & $(0.144)$ \\
\hline \multirow{3}{*}{$\begin{array}{l}\text { Newness_general* Context } \\
\text { similarity (prior entries vs. } \\
\text { focal entry) }\end{array}$} & & & & $0.204^{* *}$ \\
\hline & & & & $(0.080)$ \\
\hline & & & & \\
\hline \multirow[t]{2}{*}{ Constant } & $2.335^{* * *}$ & $2.914^{* * *}$ & $2.831^{* * *}$ & $2.803^{* * *}$ \\
\hline & $(0.374)$ & $(0.530)$ & $(0.532)$ & $(0.534)$ \\
\hline Industry dummy & yes & yes & yes & yes \\
\hline Year dummy & yes & yes & yes & yes \\
\hline Observations & 418 & 418 & 418 & 418 \\
\hline Log pseudo likelihood & -752.564 & -739.286 & -738.085 & -735.010 \\
\hline Pseudo $\mathrm{R}^{2}$ & 0.167 & 0.182 & 0.183 & 0.186 \\
\hline AIC & 1565.129 & 1550.573 & 1550.170 & 1546.019 \\
\hline
\end{tabular}

Notes: Robust standard errors in parentheses

${ }^{*} p<0.1,{ }^{* *} p<0.05,{ }^{* * *} p<0.01$ 
Table 5 Probit model and Negative binominal model on comparison

\begin{tabular}{|c|c|c|}
\hline & $\begin{array}{c}\text { Subsequent location } \\
\text { choice }\end{array}$ & $\begin{array}{c}\text { The number of OFDI } \\
\text { incidents }\end{array}$ \\
\hline & model 1 & model 2 \\
\hline Location importance of host country & $\begin{array}{c}0.531 \\
(2.474)\end{array}$ & $\begin{array}{l}2.347^{* * *} \\
(0.623)\end{array}$ \\
\hline Institutional distance & $\begin{array}{c}-0.298^{* * *} \\
(0.096)\end{array}$ & $\begin{array}{c}-0.095^{* * *} \\
(0.023)\end{array}$ \\
\hline Cultural distance & $\begin{array}{c}0.003 \\
(0.019)\end{array}$ & $\begin{array}{l}0.011^{* *} \\
(0.005)\end{array}$ \\
\hline Administrative distance & $\begin{array}{l}-0.001 \\
(0.007)\end{array}$ & $\begin{array}{l}-0.001 \\
(0.001)\end{array}$ \\
\hline Demographic distance & $\begin{array}{c}-0.058^{* * *} \\
(0.018)\end{array}$ & $\begin{array}{l}-0.001 \\
(0.004)\end{array}$ \\
\hline Geographic distance & $\begin{array}{l}-0.043 \\
(0.173)\end{array}$ & $\begin{array}{c}0.046 \\
(0.034)\end{array}$ \\
\hline General experience & $\begin{array}{c}0.001 \\
(0.012)\end{array}$ & $\begin{array}{c}-0.009^{* * *} \\
(0.002)\end{array}$ \\
\hline Host-specific experience & $\begin{array}{c}0.092 \\
(0.072)\end{array}$ & $\begin{array}{l}0.153^{* * *} \\
(0.010)\end{array}$ \\
\hline State-ownership share & $\begin{array}{c}0.433 \\
(0.436)\end{array}$ & $\begin{array}{c}0.047 \\
(0.110)\end{array}$ \\
\hline OFDI flow & $\begin{array}{c}0.021 \\
(0.018)\end{array}$ & $\begin{array}{l}-0.003 \\
(0.005)\end{array}$ \\
\hline Firm age & $\begin{array}{l}-0.000 \\
(0.019)\end{array}$ & $\begin{array}{l}-0.007 \\
(0.005)\end{array}$ \\
\hline Firm size & $\begin{array}{l}-0.150^{* *} \\
(0.076)\end{array}$ & $\begin{array}{l}-0.039^{* *} \\
(0.020)\end{array}$ \\
\hline Newness_location-specific & & $\begin{array}{l}0.061^{* * *} \\
(0.006)\end{array}$ \\
\hline Newness_the most recent & $\begin{array}{l}0.260^{*} \\
(0.136)\end{array}$ & $\begin{array}{l}0.071^{* *} \\
(0.033)\end{array}$ \\
\hline $\begin{array}{l}\text { Newness_the most recent+ } \\
\text { Newness_location-specific }\end{array}$ & $\begin{array}{l}0.069^{*} \\
(0.038)\end{array}$ & \\
\hline Newness_the most recent+ Newness_general & & $\begin{array}{c}0.019 \\
(0.018)\end{array}$ \\
\hline Constant & $\begin{array}{c}0.450 \\
(0.570)\end{array}$ & $\begin{array}{l}0.636^{* * *} \\
(0.153)\end{array}$ \\
\hline Industry dummy & Yes & Yes \\
\hline Year dummy & Yes & Yes \\
\hline Observations & 410 & 418 \\
\hline Log pseudo likelihood & -197.296 & -516.719 \\
\hline Pseudo $\mathrm{R}^{2}$ & 0.215 & 0.307 \\
\hline AIC & 454.592 & 1097.439 \\
\hline
\end{tabular}

Notes: Robust standard errors in parentheses

${ }^{*} p<0.1,{ }^{* *} p<0.05,{ }^{* * *} p<0.01$ 
Table 6 Robustness test: Outcome expectancy as continuous variables

\begin{tabular}{|c|c|c|c|c|}
\hline \multicolumn{5}{|c|}{ Subsequent location choice } \\
\hline & model 1 & model 2 & model 3 & model 4 \\
\hline \multirow{4}{*}{$\begin{array}{l}\text { Location importance of } \\
\text { host country } \\
\text { Institutional distance }\end{array}$} & 0.240 & -0.547 & -0.433 & -0.949 \\
\hline & $(2.343)$ & $(2.411)$ & $(2.551)$ & $(2.506)$ \\
\hline & $-0.283^{* * *}$ & $-0.199^{* *}$ & $-0.212^{* *}$ & $-0.206^{* *}$ \\
\hline & $(0.096)$ & $(0.100)$ & $(0.103)$ & $(0.100)$ \\
\hline \multirow[t]{2}{*}{ Cultural distance } & 0.005 & 0.001 & 0.006 & -0.003 \\
\hline & $(0.016)$ & $(0.017)$ & $(0.017)$ & $(0.017)$ \\
\hline \multirow[t]{2}{*}{ Administrative distance } & -0.001 & -0.002 & -0.001 & -0.001 \\
\hline & $(0.006)$ & $(0.006)$ & $(0.006)$ & $(0.006)$ \\
\hline \multirow[t]{2}{*}{ Demographic distance } & $-0.055^{* * *}$ & $-0.064^{* * * *}$ & $-0.062^{* * * *}$ & $-0.065^{* * * *}$ \\
\hline & $(0.017)$ & $(0.018)$ & $(0.017)$ & $(0.018)$ \\
\hline \multirow[t]{2}{*}{ Geographic distance } & -0.079 & -0.131 & -0.211 & -0.104 \\
\hline & $(0.166)$ & $(0.190)$ & $(0.193)$ & $(0.190)$ \\
\hline \multirow[t]{2}{*}{ General experience } & 0.002 & 0.008 & 0.007 & 0.008 \\
\hline & $(0.012)$ & $(0.011)$ & $(0.011)$ & $(0.011)$ \\
\hline \multirow[t]{2}{*}{ Host-specific experience } & 0.093 & 0.037 & 0.030 & 0.066 \\
\hline & $(0.091)$ & $(0.077)$ & $(0.082)$ & $(0.086)$ \\
\hline \multirow[t]{2}{*}{ State-ownership share } & 0.439 & 0.477 & 0.455 & 0.226 \\
\hline & $(0.513)$ & $(0.519)$ & $(0.530)$ & $(0.513)$ \\
\hline \multirow[t]{2}{*}{ OFDI flow } & 0.009 & 0.012 & 0.009 & 0.011 \\
\hline & $(0.020)$ & $(0.022)$ & $(0.022)$ & $(0.023)$ \\
\hline \multirow[t]{2}{*}{ Firm age } & 0.020 & 0.022 & 0.025 & 0.019 \\
\hline & $(0.017)$ & $(0.017)$ & $(0.017)$ & $(0.019)$ \\
\hline \multirow[t]{2}{*}{ Firm size } & $-0.177^{* *}$ & $-0.177^{*}$ & -0.144 & $-0.181^{*}$ \\
\hline & $(0.090)$ & $(0.098)$ & $(0.101)$ & $(0.097)$ \\
\hline \multirow[t]{2}{*}{ Newness_the most recent } & $0.294^{* *}$ & $0.299^{*}$ & $0.303^{*}$ & $0.308^{*}$ \\
\hline & $(0.144)$ & $(0.155)$ & $(0.155)$ & $(0.174)$ \\
\hline \multirow[t]{2}{*}{ Newness_location-specific } & $0.068^{*}$ & $0.071^{*}$ & $0.074^{*}$ & 0.063 \\
\hline & $(0.040)$ & $(0.041)$ & $(0.041)$ & $(0.040)$ \\
\hline \multirow[t]{2}{*}{ Outcome expectancy } & & -0.051 & -0.084 & -0.020 \\
\hline & & $(0.061)$ & $(0.062)$ & $(0.064)$ \\
\hline Context similarity & & $1.653^{* * *}$ & $1.726^{* * *}$ & $1.708^{* * *}$ \\
\hline $\begin{array}{l}\text { (the most recent entry vs. } \\
\text { focal entry) }\end{array}$ & & $(0.467)$ & $(0.475)$ & $(0.461)$ \\
\hline Newness_the most recent* & & & $0.225^{* *}$ & \\
\hline Outcome expectancy & & & $(0.110)$ & \\
\hline Newness_the most recent* & & & & $1.577^{* *}$ \\
\hline Context similarity & & & & $(0.620)$ \\
\hline $\begin{array}{l}\text { (the most recent entry vs. } \\
\text { focal entry) }\end{array}$ & & & & \\
\hline \multirow[t]{2}{*}{ Constant } & 0.414 & 0.261 & 0.182 & 0.256 \\
\hline & $(0.728)$ & $(0.765)$ & $(0.785)$ & $(0.801)$ \\
\hline Year dummy & Yes & Yes & Yes & Yes \\
\hline Industry dummy & Yes & Yes & Yes & Yes \\
\hline Observations & 410 & 410 & 410 & 410 \\
\hline Log pseudo likelihood & -199.021 & -188.609 & -188.157 & -183.581 \\
\hline Pseudo $\mathrm{R}^{2}$ & 0.213 & 0.254 & 0.258 & 0.274 \\
\hline AIC & 456.041 & 439.218 & 440.313 & 431.161 \\
\hline
\end{tabular}

Notes: Robust standard errors in parentheses

${ }^{*} p<0.1,{ }^{* *} p<0.05,{ }^{* * *} p<0.01$ 
Table 7 Robustness check: Six dimensions of Institutional environment

\begin{tabular}{|c|c|c|c|c|c|c|}
\hline & & Sub: & quent loca & on choice & & \\
\hline & model 1 & model 2 & model 3 & model 4 & model 5 & model 6 \\
\hline Location importance of host country & 1.431 & 1.044 & 0.544 & 0.841 & 0.113 & 0.230 \\
\hline & $(2.793)$ & $(2.641)$ & $(2.735)$ & $(2.712)$ & (2.692) & $(2.681)$ \\
\hline Institutional distance & $-0.260^{* * * * *}$ & $-0.244^{* *}$ & $-0.260^{* * *}$ & $-0.262^{* *}$ & $-0.260^{* *}$ & $-0.266^{* * *}$ \\
\hline & $(0.096)$ & $(0.105)$ & $(0.106)$ & $(0.108)$ & $(0.105)$ & $(0.101)$ \\
\hline Cultural distance & 0.002 & 0.002 & -0.000 & -0.004 & -0.000 & -0.000 \\
\hline & $(0.016)$ & $(0.018)$ & $(0.017)$ & $(0.017)$ & $(0.016)$ & $(0.016)$ \\
\hline Administrative distance & -0.009 & -0.007 & -0.008 & -0.008 & -0.007 & -0.007 \\
\hline & $(0.008)$ & $(0.008)$ & $(0.008)$ & $(0.008)$ & $(0.008)$ & $(0.008)$ \\
\hline Demographic distance & $-0.038^{* *}$ & $-0.044^{* *}$ & $-0.048^{* * *}$ & $-0.048^{* * * *}$ & $-0.046^{* * * *}$ & 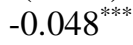 \\
\hline & $(0.016)$ & $(0.018)$ & $(0.017)$ & $(0.017)$ & $(0.017)$ & $(0.017)$ \\
\hline Geographic distance & 0.011 & 0.015 & -0.018 & -0.014 & -0.022 & -0.041 \\
\hline & $(0.159)$ & $(0.165)$ & $(0.158)$ & $(0.165)$ & $(0.152)$ & $(0.155)$ \\
\hline General experience & -0.003 & -0.004 & -0.004 & -0.003 & -0.003 & -0.003 \\
\hline & $(0.010)$ & $(0.011)$ & $(0.011)$ & $(0.011)$ & $(0.011)$ & $(0.011)$ \\
\hline Host-specific experience & 0.148 & 0.142 & $0.152^{*}$ & 0.148 & $0.157^{*}$ & $0.156^{*}$ \\
\hline & $(0.097)$ & $(0.089)$ & $(0.092)$ & $(0.092)$ & $(0.094)$ & $(0.094)$ \\
\hline State-ownership share & 0.480 & 0.615 & 0.473 & 0.546 & 0.456 & 0.429 \\
\hline & $(0.484)$ & $(0.489)$ & $(0.479)$ & $(0.485)$ & $(0.478)$ & $(0.475)$ \\
\hline OFDI flow & $0.042^{* *}$ & 0.027 & 0.021 & 0.021 & 0.021 & 0.021 \\
\hline & $(0.018)$ & $(0.019)$ & $(0.020)$ & $(0.019)$ & $(0.020)$ & $(0.020)$ \\
\hline Firm age & -0.008 & -0.003 & -0.000 & 0.000 & -0.000 & 0.001 \\
\hline & $(0.020)$ & $(0.020)$ & $(0.020)$ & $(0.020)$ & $(0.020)$ & $(0.020)$ \\
\hline Firm size & -0.076 & -0.105 & -0.127 & -0.138 & -0.136 & -0.138 \\
\hline & $(0.091)$ & $(0.087)$ & $(0.091)$ & $(0.091)$ & $(0.092)$ & $(0.092)$ \\
\hline Newness_the most recent & 0.148 & 0.165 & 0.200 & 0.192 & 0.186 & 0.218 \\
\hline & $(0.160)$ & $(0.152)$ & $(0.160)$ & $(0.157)$ & $(0.161)$ & $(0.157)$ \\
\hline Newness_location-specific & 0.051 & 0.051 & 0.055 & 0.055 & 0.056 & 0.056 \\
\hline & $(0.045)$ & $(0.043)$ & $(0.043)$ & $(0.043)$ & $(0.043)$ & $(0.042)$ \\
\hline Outcome expectancy & 0.192 & 0.250 & 0.253 & 0.254 & 0.241 & 0.229 \\
\hline & $(0.164)$ & $(0.163)$ & $(0.169)$ & $(0.169)$ & $(0.170)$ & $(0.170)$ \\
\hline $\begin{array}{l}\text { Context similarity (Voice of } \\
\text { accountability) }\end{array}$ & $\begin{array}{c}0.428 \\
(0.438)\end{array}$ & & & & & \\
\hline $\begin{array}{l}\text { Newness_the most recent } * \text { Context } \\
\text { similarity (Voice of accountability) }\end{array}$ & $\begin{array}{l}1.145^{*} \\
(0.599)\end{array}$ & & & & & \\
\hline Context similarity (Political stability) & & 0.67 & & & & \\
\hline & & $(0.434)$ & & & & \\
\hline $\begin{array}{l}\text { Newness_the most recent } * \text { Context } \\
\text { similarity (Political stability) }\end{array}$ & & $\begin{array}{l}1.024^{*} \\
(0.574)\end{array}$ & & & & \\
\hline Context similarity (Government & & & 0.389 & & & \\
\hline effectiveness) & & & $(0.432)$ & & & \\
\hline Newness_the most recent $*$ Context & & & $1.460^{* * *}$ & & & \\
\hline $\begin{array}{l}\text { similarity (Government effectiveness) } \\
\text { Context similarity (Regulatory quality) }\end{array}$ & & & & 0.709 & & \\
\hline & & & & $(0.483)$ & & \\
\hline Newness_the most recent $*$ Context & & & & $\begin{array}{l}1.941^{* * *} \\
(0.574)\end{array}$ & & \\
\hline $\begin{array}{l}\text { similarity (Regulatory quality) } \\
\text { Context similarity (Rule of law) }\end{array}$ & & & & & 0.286 & \\
\hline & & & & & & \\
\hline Newness_the most recent $*$ Context & & & & & $1.497^{* * * *}$ & \\
\hline similarity (Rule of law) & & & & & $(0.521)$ & \\
\hline Context similarity (Control of corruption) & & & & & & $\begin{array}{c}0.450 \\
(0.473)\end{array}$ \\
\hline $\begin{array}{l}\text { Newness_the most recent } * \text { Context } \\
\text { similarity (Control of corruption) }\end{array}$ & & & & & & $\begin{array}{l}1.721^{* * *} \\
(0.618)\end{array}$ \\
\hline
\end{tabular}


Table 7 continued

\begin{tabular}{lcccccc}
\hline Constant & 0.120 & 0.144 & 0.175 & 0.111 & 0.167 & 0.174 \\
& $(0.720)$ & $(0.705)$ & $(0.729)$ & $(0.731)$ & $(0.731)$ & $(0.723)$ \\
Year dummy & Yes & Yes & Yes & Yes & Yes & Yes \\
Industry dummy & Yes & Yes & Yes & Yes & Yes & Yes \\
Observations & 410 & 410 & 410 & 410 & 410 & 410 \\
Log pseudo likelihood & -198.905 & -199.095 & -196.481 & -195.402 & -195.706 & -195.126 \\
Pseudo R & 0.206 & 0.205 & 0.216 & 0.220 & 0.219 & 0.221 \\
AIC & 461.811 & 462.191 & 456.962 & 454.804 & 455.413 & 454.251 \\
\hline
\end{tabular}

Notes: Robust standard errors in parentheses $* p<0.1,{ }^{* *} p<0.05,{ }^{* * *} p<0.01$

Table 8 Marginal effects: Probit model

\begin{tabular}{lcccccc}
\hline & $\mathrm{dy} / \mathrm{dx}$ & Std.Err. & $\mathrm{z}$ & $\mathrm{P}>|\mathrm{z}|$ & \multicolumn{2}{c}{$[95 \%$ Conf.Interval] } \\
\hline Newness_the most recent & 0.089 & 0.038 & 2.330 & 0.020 & 0.014 & 0.164 \\
Newness_location-specific & 0.019 & 0.011 & 1.700 & 0.088 & -0.003 & 0.040 \\
Location importance of host country & 0.143 & 0.649 & 0.220 & 0.825 & -1.129 & 1.416 \\
Institutional distance & -0.080 & 0.026 & -3.100 & 0.002 & -0.131 & -0.030 \\
Cultural distance & 0.001 & 0.004 & 0.200 & 0.845 & -0.008 & 0.009 \\
Administrative distance & 0.000 & 0.002 & -0.180 & 0.854 & -0.004 & 0.003 \\
Demographic distance & -0.016 & 0.005 & -3.420 & 0.001 & -0.024 & -0.007 \\
Geographic distance & -0.012 & 0.046 & -0.260 & 0.798 & -0.102 & 0.078 \\
General experience & 0.000 & 0.003 & 0.110 & 0.912 & -0.006 & 0.007 \\
Host-specific experience & 0.025 & 0.025 & 1.010 & 0.312 & -0.023 & 0.073 \\
State-ownership share & 0.117 & 0.138 & 0.850 & 0.395 & -0.153 & 0.387 \\
OFDI flow & 0.006 & 0.005 & 1.270 & 0.204 & -0.003 & 0.015 \\
Firm age & 0.000 & 0.006 & -0.010 & 0.990 & -0.011 & 0.011 \\
Firm size & -0.041 & 0.024 & -1.690 & 0.091 & -0.088 & 0.006 \\
Industry dummy & yes & yes & yes & yes & yes & yes \\
Year dummy & yes & yes & yes & yes & yes & yes \\
\hline
\end{tabular}

Table 9 Marginal effects: Negative binominal model

\begin{tabular}{lcccccc}
\hline Variables & $\mathrm{dy} / \mathrm{dx}$ & Std.Error & $\mathrm{z}$ & $\mathrm{P}>|\mathrm{z}|$ & \multicolumn{2}{c}{$[95 \%$ Conf.Interval] } \\
Newness_the most recent & 0.324 & 0.154 & 2.1 & 0.036 & 0.022 & 0.627 \\
Newness_general & 0.089 & 0.034 & 2.63 & 0.009 & 0.023 & 0.155 \\
Newness_location-specific & 0.293 & 0.090 & 3.24 & 0.001 & 0.115 & 0.470 \\
Location importance of host country & 0.367 & 3.128 & 0.12 & 0.907 & -5.763 & 6.497 \\
Institutional distance & -0.329 & 0.129 & -2.54 & 0.011 & -0.583 & -0.075 \\
Cultural distance & -0.015 & 0.024 & -0.63 & 0.530 & -0.062 & 0.032 \\
Administrative distance & 0.011 & 0.010 & 1.07 & 0.284 & -0.009 & 0.030 \\
Demographic distance & -0.005 & 0.020 & -0.23 & 0.817 & -0.044 & 0.035 \\
Geographic distance & -0.298 & 0.181 & -1.65 & 0.099 & -0.653 & 0.056 \\
General experience & -0.019 & 0.014 & -1.36 & 0.173 & -0.047 & 0.008 \\
Host-specific experience & -0.036 & 0.044 & -0.82 & 0.409 & -0.122 & 0.050 \\
State-ownership share & 2.468 & 0.919 & 2.69 & 0.007 & 0.667 & 4.269 \\
OFDI flow & 0.009 & 0.023 & 0.37 & 0.711 & -0.037 & 0.054 \\
Firm age & 0.016 & 0.024 & 0.66 & 0.508 & -0.032 & 0.064 \\
Firm size & -0.062 & 0.108 & -0.57 & 0.567 & -0.273 & 0.150 \\
Industry dummy & yes & yes & yes & yes & yes & yes \\
Year dummy & yes & yes & yes & yes & yes & yes \\
\hline
\end{tabular}

